\section{Phylogeny and polyphasic taxonomy of Caulobacter species. Proposal of Maricaulis gen. nov. with Maricaulis maris (Poindexter) comb. nov. as the type species, and emended description of the genera Brevundimonas and Caulobacter}

\author{
Wolf-Rainer Abraham, ${ }^{1}$ Carsten Strömpl, ${ }^{1}$ Holger Meyer, ${ }^{1}$ \\ Sabine Lindholst, ${ }^{1}$ Edward R. B. Moore, ${ }^{1}$ Ruprecht Christ, ${ }^{1}$ \\ Marc Vancanneyt, ${ }^{2}$ B. J. Tindall, ${ }^{3}$ Antonio Bennasar, ${ }^{1}$ John Smit ${ }^{4}$ \\ and Michael Tesar ${ }^{1}$
}

1 Gesellschaft für Biotechnologische Forschung $\mathrm{mbH}$, Mascheroder Weg 1, D38124 Braunschweig, Germany

2 Laboratorium voor Microbiologie, Universiteit Gent, Gent, Belgium

3 Deutsche Sammlung von Mikroorganismen und Zellkulturen, Braunschweig, Germany

4 Dept of Microbiology and Immunology, University of British Columbia, Vancouver, British Columbia, Canada
Author for correspondence: Wolf-Rainer Abraham. Tel: +495316181 419. Fax: +495316181411. e-mail: wab@gbf.de

The genus Caulobacter is composed of prosthecate bacteria often specialized for oligotrophic environments. The taxonomy of Caulobacter has relied primarily upon morphological criteria: a strain that visually appeared to be a member of the Caulobacter has generally been called one without challenge. A polyphasic approach, comprising 165 rDNA sequencing, profiling restriction fragments of 165-23S rDNA interspacer regions, lipid analysis, immunological profiling and salt tolerance characterizations, was used to clarify the taxonomy of 76 strains of the genera Caulobacter, Brevundimonas, Hyphomonas and Mycoplana. The described species of the genus Caulobacter formed a paraphyletic group with Caulobacter henricii, Caulobacter fusiformis, Caulobacter vibrioides and Mycoplana segnis (Caulobacter segnis comb. nov.) belonging to Caulobacter sensu stricto. Caulobacter bacteroides (Brevundimonas bacteroides comb. nov.), C. henricii subsp. aurantiacus (Brevundimonas aurantiaca comb. nov.), Caulobacter intermedius (Brevundimonas intermedia comb. nov.), Caulobacter subvibrioides (Brevundimonas subvibrioides comb. nov.), C. subvibrioides subsp. albus (Brevundimonas alba comb. nov.), Caulobacter variabilis (Brevundimonas variabilis comb. nov.) and Mycoplana bullata belong to the genus Brevundimonas. The halophilic species Caulobacter maris and Caulobacter halobacteroides are different from these two genera and form the genus Maricaulis gen. nov. with Maricaulis maris as the type species. Caulobacter leidyia was observed to cluster with species of the genus Sphingomonas. Caulobacter crescentus is synonymous with $C$. vibrioides and C. halobacteroides is synonymous with Maricaulis maris as determined by these analyses and DNA-DNA hybridization. Biomarkers discerning these different genera were determined. The necessary recombinations have been proposed and a description of Maricaulis is presented.

Keywords: Caulobacter, Brevundimonas, Maricaulis gen. nov., Mycoplana, Hyphomonas 


\section{INTRODUCTION}

The genus Caulobacter is composed of dimorphic, prosthecate bacteria. In these prokaryotes, reproduction results in the separation of two cells that are morphologically and behaviourally different from each other. One sibling is non-motile, sessile by virtue of adhesive material and prosthecate, possessing at least one elongated, cylindrical appendage (a prostheca) that is an outgrowth of the cell envelope, including the outer membrane, the peptidoglycan layer and the cell membrane (Staley, 1968). The other sibling is flagellated, bearing one polar flagellum, by which it is motile. The mode of reproduction of the dimorphic prosthecate bacteria is unique as a regular feature of a prokaryotic reproductive cycle. It is regarded as a reflection of an ecological programme helping to disperse the population at each generation, thereby minimizing competition for resources.

In each species studied so far, the motile cell grows less actively than its prosthecate sibling. Progress toward reproduction is initiated in the swarmers only after this period of motility. It is consistent with this developmental and reproductive habit that these bacteria exhibit the physiological properties of oligotrophs (Poindexter, 1981a, b) and, most importantly, the tolerance of prolonged nutrient scarcity. Once isolated, individual strains may tolerate much higher nutrient concentrations than are useful for their enrichment and isolation. All caulobacteria are oxybiotic and grow in well-aerated cultures.

Caulobacteria are ubiquitous in water. As typical aquatic bacteria, they may be second only to pseudomonads in the breadth of their distribution and numbers (Lapteva, 1987). These two bacterial groups together are presumed to be responsible for considerable mineralization of dissolved organic material in aquatic environments, whereby the oligotrophic caulobacters are especially important when nutrient concentrations and ambient temperatures are low (Staley et al., 1987). Practically any type of seawater contains Caulobacter (Jannasch \& Jones, 1960; Anast \& Smit, 1988) and, further, MacRae \& Smit (1991) reported the ready detection of Caulobacter in highly aerobic activated sewage sludge.

The first isolation of a Caulobacter sp. was reported by Loeffler (1890). He noticed the unusually low nutrient requirements of the strain. He could not assign the strain to a known taxon and named this 'höchst merkwürdigen Organismus' 'Vibrio (?) spermatozoides'. Later, Henrici \& Johnson (1935) described the genus Caulobacter with Caulobacter vibrioides as the type species. Then, Poindexter (1964) enlarged the monotypic genus considerably by describing nine species and two subspecies, and later added Caulobacter variabilis (Poindexter, 1989).

Henrici \& Johnson (1935) did not isolate Caulobacter vibrioides and therefore a type strain was not named. Poindexter (1964) proposed strain CB51 as the neotype strain of $C$. vibrioides (Poindexter \& Lewis, 1966).
Strain CB51 ${ }^{\mathrm{T}}$ was obtained independently from the All-Russian Collection of Microorganisms (VKM B$1496^{\mathrm{T}}$ ) and from J. T. Staley (= DSM $9893^{\mathrm{T}}$ ).

Fatty acids of Caulobacter spp. were determined by Carter \& Schmidt (1976) and polar lipids have been analysed by various groups (Minnikin et al., 1973; Wilkinson, 1969; Wilkinson \& Bell, 1971; Andreev et al., 1986; Batrakov et al., 1996, 1997). Using 5S rRNA sequences, Stackebrandt et al. (1988) determined the phylogenetic position of Caulobacter crescentus within the $\alpha$-subclass of the Proteobacteria; similar results were reported two years later by Nikitin et al. (1990). Anast \& Smit (1988) were the first to determine differences between freshwater and marine caulobacteria on a large set of strains. In a pioneering study, Stahl et al. (1992) sequenced the 16S rRNA of several Caulobacter isolates. Although sequences of type strains of Caulobacter species were not included in this study and a strain wrongly labelled as Caulobacter subvibrioides was included (Sly et al., 1997), this study revealed, for the first time, that Caulobacter actually forms two different lineages, one comprising the freshwater and brackish water Caulobacter spp. and the other comprising the marine forms. Stahl et al. (1992) also showed that Brevundimonas diminuta (Segers et al., 1994) clusters within the group of freshwater Caulobacter spp. The 16S rDNA sequences of Mycoplana segnis and Mycoplana bullata (Yanagi \& Yamasato, 1993) also fall in the freshwater Caulobacter/Brevundimonas cluster and thus complicate the taxonomy further.

As caulobacteria are ubiquitous in water samples and are believed to play an important role in the carbon cycling within their habitats, the intent of the present study was to evaluate the diversity of freshwater and marine caulobacters using lipid analysis, immunological profiling and $16 \mathrm{~S}$ rRNA gene sequences to compare these results with physiological data. Because previous studies (Stahl et al., 1992) revealed a close phylogenetic distance between Caulobacter, Hyphomonas jannaschiana, Mycoplana bullata, Mycoplana segnis and $B$. diminuta, strains of these genera were also included in this study.

\section{METHODS}

Strains and culture conditions. The strains in this study were obtained from the American Type Culture Collection (ATCC), the Deutsche Sammlung von Mikroorganismen und Zellkulturen (DSMZ; DSM strains), the Laboratorium voor Microbiologie, Universiteit Gent, Belgium (LMG strains), the All-Russian Collection of Microorganisms (VKM), from Ingo Fritz at the GBF (Brevundimonas sp. BO.07 and BO.10) and from the Dept of Microbiology and Immunology at the University of British Columbia (CB, FWC and MCS strains). Table 1 shows the origin of the isolates.

All strains were grown in medium PYEM with the exception of Caulobacter maris ATCC $15268^{\mathrm{T}}$, Caulobacter halobacteroides ATCC $15269^{\mathrm{T}}$, Hyphomonas spp. and all Caulo- 
Table 1. List of strains used in this study including their serum reactions and the accession numbers of the newly determined 16S rRNA gene sequences

\begin{tabular}{|c|c|c|c|}
\hline Strain & Source & $\begin{array}{l}\text { Positive } \\
\text { reaction } \\
\text { with } \\
\text { serum: }\end{array}$ & $\begin{array}{l}\text { Accession } \\
\text { no. }\end{array}$ \\
\hline Brevundimonas diminuta $\mathrm{LMG} 2089^{\mathrm{T}}$ & Freshwater & SMT2 & AJ227778 \\
\hline Brevundimonas diminuta LMG 2337 & Blood, patient with endocarditis & SMT2 & AJ 227779 \\
\hline Brevundimonas sp. BO.07 & $\begin{array}{l}\text { Marine isolate, sampling depth } 110 \mathrm{~m} \text {, offshore } \\
\text { Nice/Mediterranean Sea }\end{array}$ & SMT2 & $\mathrm{AJ} 227800$ \\
\hline Brevundimonas sp. BO.10 & $\begin{array}{l}\text { Marine isolate, sampling depth } 150 \mathrm{~m} \text {, offshore } \\
\text { Nice/Mediterranean Sea }\end{array}$ & SMT2 & AJ227801 \\
\hline Brevundimonas vesicularis $\mathrm{LMG} 2350^{\mathrm{T}}$ & Leech (Hirudo sp.), urinary bladder, epithelium & SMT2 & AJ 227780 \\
\hline Brevundimonas vesicularis LMG 11141 & Pleural liquid, Hospital, Brussels, Belgium & SMT2 & AJ227781 \\
\hline Caulobacter bacteroides LMG $15096^{\mathrm{T}}$ & Freshwater lake & SMT2 & AJ227782 \\
\hline Caulobacter crescentus CB15 & Pond water & SMT7 & AJ 227757 \\
\hline Caulobacter crescentus $\mathrm{CB} 2^{\mathrm{T}}$ & Tap water & SMT7 & AJ 227756 \\
\hline Caulobacter fusiformis ATCC $15257^{\mathrm{T}}$ & Pond water & SMT7 & $\mathrm{AJ} 227759$ \\
\hline Caulobacter halobacteroides ATCC $15269^{\mathrm{T}}$ & Filtered seawater & SMT25 & AJ 227803 \\
\hline Caulobacter henricii ATCC $15253^{\mathrm{T}}$ & Freshwater pond & SMT7 & AJ 227758 \\
\hline Caulobacter henricii subsp. aurantiacus DSM 4731 & Contaminated Chlorella culture, CB-R ${ }^{\mathrm{T}}$ & SMT2 & AJ227787 \\
\hline Caulobacter intermedius ATCC $15262^{\mathrm{T}}$ & Pond water & SMT2 & AJ 227786 \\
\hline Caulobacter leidyia ATCC $15260^{\mathrm{T}}$ & Millipede hind gut & NR & $\mathrm{AJ} 227812$ \\
\hline Caulobacter leidyia DSM $4733^{\mathrm{T}}$ & & NR & \\
\hline Caulobacter maris ATCC $15268^{\mathrm{T}}$ & Filtered seawater & SMT25 & AJ 227802 \\
\hline Caulobacter sp. DSM 6811 (= ATCC 15256) & & NT & AJ227789 \\
\hline Caulobacter sp. DSM $6812(=$ ATCC 15267) & Pond and tap water mixture & NT & AJ 227790 \\
\hline Caulobacter sp. DSM 10556 (= ATCC 15263) & Pond water & NT & AJ227788 \\
\hline Caulobacter sp. DSM 10560 (= ATCC 15259) & Pond water & NT & AJ227791 \\
\hline Caulobacter sp. DSM $10670(=$ ATCC 15258) & Pond water & NT & AJ227792 \\
\hline Caulobacter sp. FWC 2 & Lake Washington, Seattle, WA, USA & SMT7 & $\mathrm{AJ} 227760$ \\
\hline Caulobacter sp. FWC 4 & $\begin{array}{l}\text { Freshwater slough adjacent to Lake Washington, } \\
\text { Seattle, WA, USA }\end{array}$ & SMT2 & AJ227793 \\
\hline Caulobacter sp. FWC 5 & $\begin{array}{l}\text { Surface water in waterlogged area, Bothell, WA, } \\
\text { USA }\end{array}$ & SMT7 & AJ227794 \\
\hline Caulobacter sp. FWC 6 & Tap water, Oakland, CA, USA & SMT7 & AJ227761 \\
\hline Caulobacter sp. FWC 7 & Tap water, Oakland, CA, USA & SMT7 & \\
\hline Caulobacter sp. FWC 8 & $\begin{array}{l}\text { Secondary treatment, activated sludge process, } \\
\text { Bio-P, Univ. British Columbia, BC, Canada }\end{array}$ & SMT7 & $\mathrm{AJ} 227762$ \\
\hline Caulobacter sp. FWC 9 & $\begin{array}{l}\text { Bench-scale secondary treatment system, fed with } \\
\text { landfill leachate, Univ. British Columbia, BC, } \\
\text { Canada }\end{array}$ & SMT7 & \\
\hline Caulobacter sp. FWC 11 & $\begin{array}{l}\text { Holding tank for raw influent sewage, Univ. British } \\
\text { Columbia, BC, Canada }\end{array}$ & SMT7 & \\
\hline Caulobacter sp. FWC 12 & $\begin{array}{l}\text { Bench-scale secondary treatment system, fed with } \\
\text { landfill leachate, Univ. British Columbia, BC, } \\
\text { Canada }\end{array}$ & SMT7 & \\
\hline Caulobacter sp. FWC 13 & $\begin{array}{l}\text { Surface water from a peat bog, Richmond, BC, } \\
\text { Canada }\end{array}$ & SMT7 & \\
\hline Caulobacter sp. FWC 14 & $\begin{array}{l}\text { Secondary treatment, activated sludge process, } \\
\text { Univ. British Columbia, BC, Canada }\end{array}$ & SMT2 & $\mathrm{AJ} 227795$ \\
\hline Caulobacter sp. FWC 15 & $\begin{array}{l}\text { Primary treatment facility for Greater Vancouver, } \\
\text { Iona Island, BC, Canada }\end{array}$ & SMT7 & \\
\hline Caulobacter sp. FWC 16 & $\begin{array}{l}\text { Primary treatment facility for Greater Vancouver, } \\
\text { Iona Island, BC, Canada }\end{array}$ & SMT7 & $\mathrm{AJ} 227763$ \\
\hline
\end{tabular}


Table 1 (cont.)

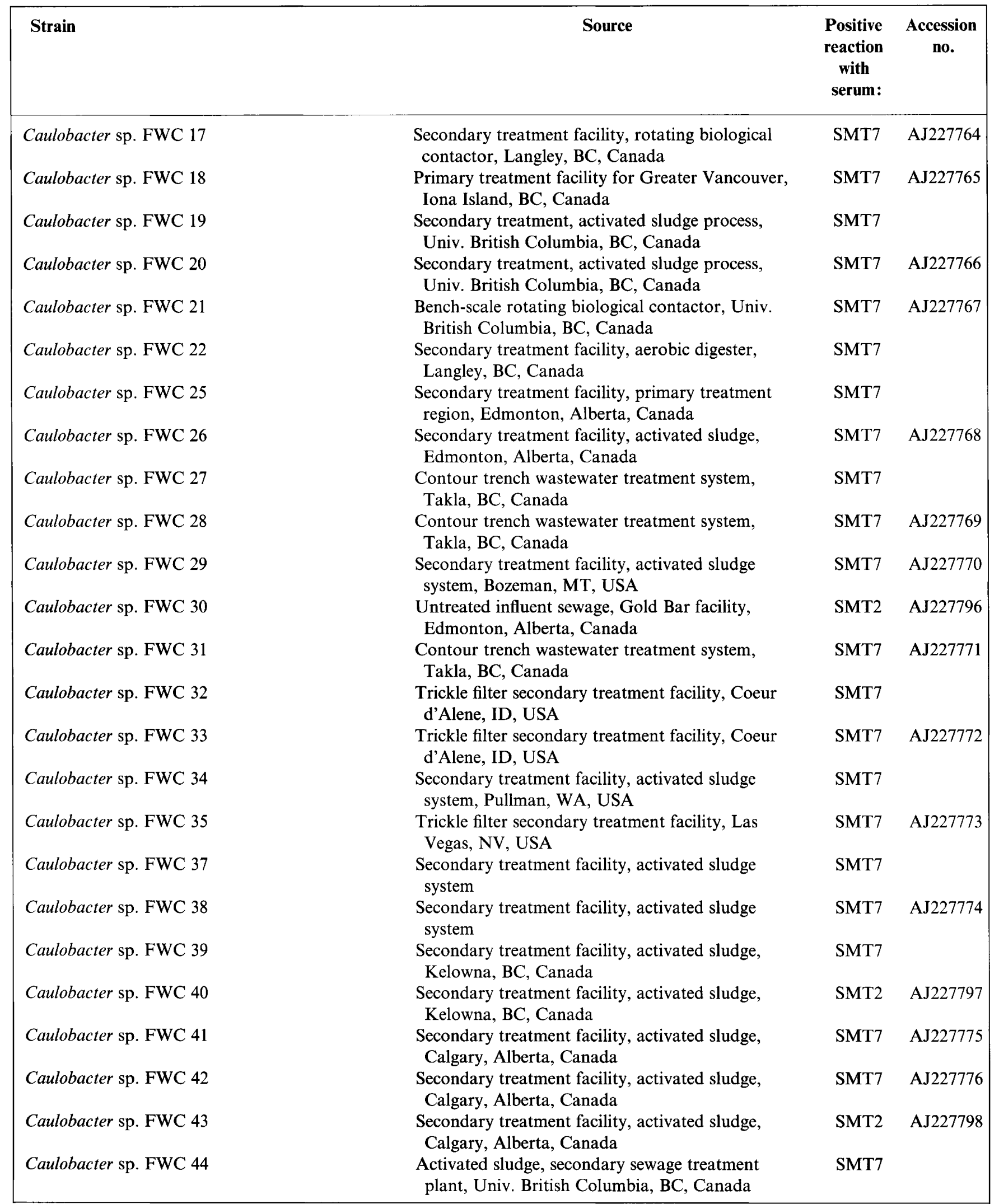


Table 1 (cont.)

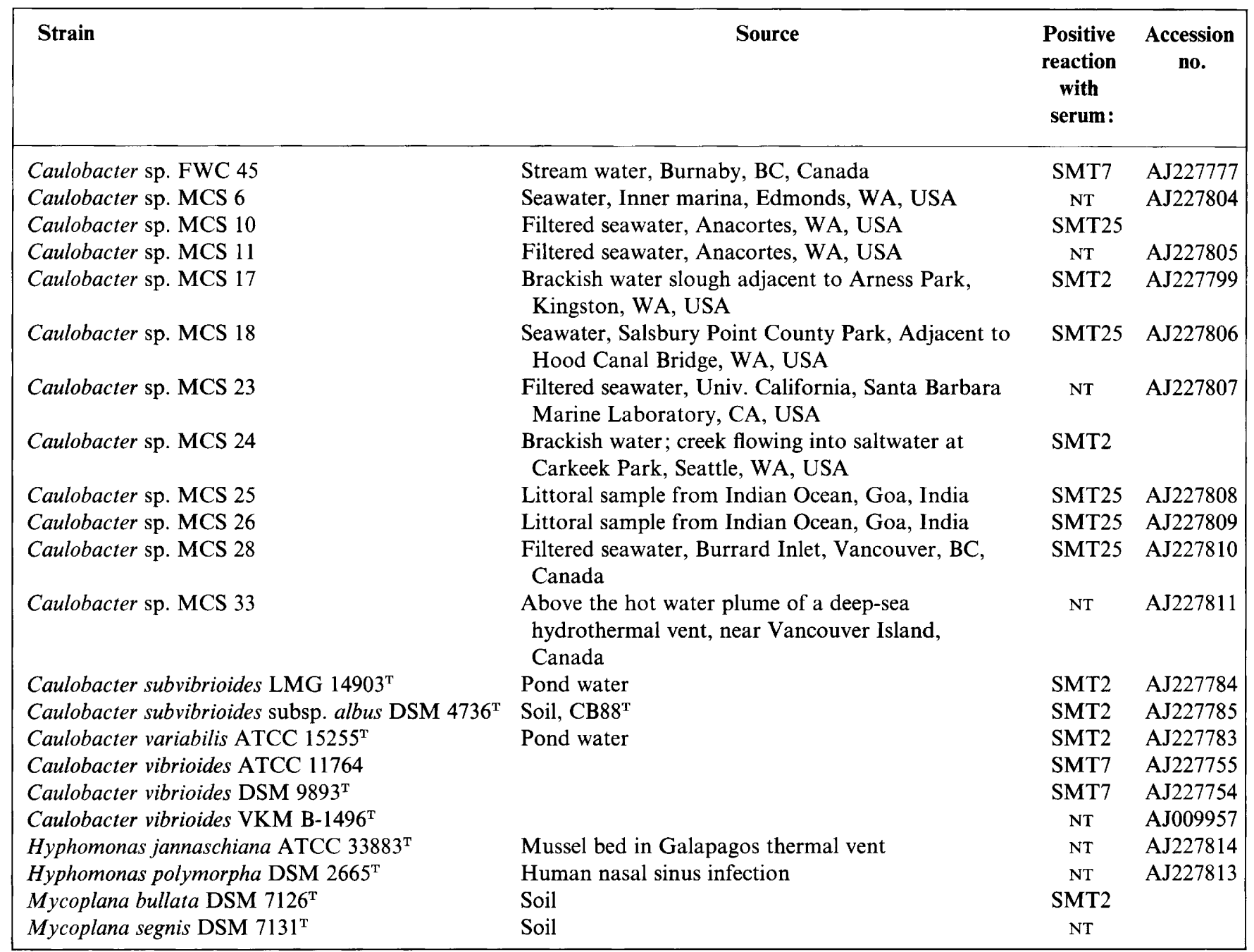

NR, No reaction with sera SMT2, SMT7 or SMT25; NT, not tested.

bacter sp. MCS strains, which were grown in the marine medium SPYEM. Freshwater Caulobacter medium PYEM contained $2 \mathrm{~g}$ peptone, $2 \mathrm{~g}$ yeast extract, $0.5 \mathrm{~g} \mathrm{NH}_{4} \mathrm{Cl}$ and $1 \mathrm{l}$ deionized water. After autoclaving and cooling, $5 \mathrm{ml}$ riboflavin $\left(0.2 \mathrm{mg} \mathrm{ml}^{-1}\right.$, filter-sterilized), $2 \mathrm{ml} 50 \%$ glucose (sterile), $1 \mathrm{ml} 20 \% \mathrm{MgSO}_{4}$ (sterile) and $1 \mathrm{ml} 10 \% \mathrm{CaCl}_{2}$ (sterile) were added. Marine Caulobacter medium SPYEM contained $30 \mathrm{~g}$ sea salts (Sigma), $0.5 \mathrm{~g} \mathrm{NH}_{4} \mathrm{Cl}$ and 11 deionized water. After autoclaving and cooling, $20 \mathrm{ml} 50 \times$ PYE [50 $\times$ PYE: $100 \mathrm{~g}$ peptone and $50 \mathrm{~g}$ yeast extract in 11

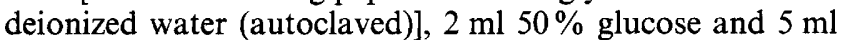
riboflavin $\left(0.2 \mathrm{mg} \mathrm{m}^{-1}\right)$ were added. The strains were incubated in 21 flasks at $30^{\circ} \mathrm{C}$, shaken at 100 r.p.m., and the biomass was harvested by centrifugation at room temperature and $5860 \mathrm{~g}$ in the late exponential phase after $72 \mathrm{~h}$.

DNA isolation and base composition. High molecular mass genomic DNA was isolated and purified with the blood and cell culture DNA kit and Genomic-tips (Qiagen) according to the manufacturer's protocols. DNA was enzymically digested using nuclease $\mathrm{P} 1$ and bacterial alkaline phosphatase, and the mean $\mathrm{G}+\mathrm{C}$ content was determined by HPLC (Tamaoka \& Komagata, 1984); G + C contents were calculated according to Mesbah et al. (1989) using nonmethylated lambda phage DNA (Sigma) as a standard.

$16 S$ rDNA sequencing and analysis. Single colonies were picked from agar, suspended in $100 \mu \mathrm{l}$ TE buffer $(10 \mathrm{mM}$ Tris/ $\mathrm{HCl}, 1 \mathrm{mM}$ EDTA, $\mathrm{pH} 8 \cdot 0$ ) and boiled for $5 \mathrm{~min}$. The lysate was centrifuged briefly and $1 \mu$ l supernatant was used for PCR, targeting the 16S rRNA genes (Medlin et al., 1988; Edwards et al., 1989) using a forward primer, hybridizing at positions 8-27, and a reverse primer, hybridizing at the complement of positions 1525-1541 (Escherichia coli 16S rRNA gene sequence numbering). PCR was carried out using conditions described previously (Karlson et al., 1993). Amplified 16S rDNA was purified using Microcon 100 microconcentrators (Amicon) and the sequences were determined directly using an Applied Biosystems 373A DNA sequencer and the protocols recommended by the manufacturer (Perkin Elmer) for Taq-polymerase-initiated cycle 
sequencing with fluorescent-dye-labelled dideoxynucleotides. The 16S rRNA sequencing primers have been described previously (Lane, 1991). The nucleotide sequences were aligned with reference 16S rRNA and 16S rRNA gene sequences using evolutionary conserved primary sequence and secondary structure (Gutell et al., 1985) as references. Evolutionary distances (Jukes \& Cantor, 1969) were calculated from nearly complete sequence-pair dissimilarities using only homologous, unambiguously determined nucleotide positions. Phylogenetic trees were constructed using the software programs of the PHYLIP package (Felsenstein, 1989).

16S-23S rDNA interspacer based analysis. DNA extractions and PCR were performed as described for $16 \mathrm{~S}$ rDNA sequencing with the following differences. The forward primer was $16 f 945$, corresponding to positions $927-945$ of the $E$. coli $16 \mathrm{~S}$ rDNA (Brosius et al., 1978) and the reverse primer was $23 \mathrm{r} 458$, corresponding to positions $458-473$ of the $E$. coli 23S rDNA (Brosius et al., 1980). The interspacer region (ISR) PCR products were digested using the tetrameric endonuclease TaqI (Boehringer Mannheim) at $65^{\circ} \mathrm{C}$, according to the supplier's recommendations. The restriction fragment products were separated by agarose $(3 \%$, $\mathrm{w} / \mathrm{v}$ ) gel electrophoresis, stained with ethidium bromide and visualized by UV excitation. For single-stranded conformational polymorphism (SSCP) analysis of the restriction fragments (Orita et al., 1989), $5 \mu$ l digested ISR PCR products was diluted $1: 1$ in denaturing solution $(99 \%$ deionized formamide, $0.05 \%$ xylene cyanol and $0.04 \%$ bromophenol blue), incubated at $95{ }^{\circ} \mathrm{C}$ for $5 \mathrm{~min}$ and placed directly into ice water to prevent reannealing of the singlestranded product. The products were electrophoresed in non-denaturing polyacrylamide precasted gels (CleanGel DNA Analysis kit; Pharmacia Biotech) on a Multiphor II Electrophoresis unit at $200 \mathrm{~V}$ for $10 \mathrm{~min}$ followed by $45 \mathrm{~min}$ at $600 \mathrm{~V}$. After electrophoresis, the gel was stained with the Plus One silver staining kit (Pharmacia Biotech) following the protocol of the manufacturer.

DNA-DNA hybridization. Chromosomal DNA of high molecular mass was isolated according to the method of Marmur (1961). Degrees of DNA-DNA binding, expressed as percentages, were determined spectrophotometrically using the initial renaturation method of De Ley et al. (1970) and the equipment and method described by Willems et al. (1989).

Whole-cell fatty acid analysis. Cells were saponified $[15 \%$ (w/v) $\left.\mathrm{NaOH}, 30 \mathrm{~min}, 100^{\circ} \mathrm{C}\right]$, methylated to fatty acid methyl esters (methanolic $\mathrm{HCl}, 10 \mathrm{~min}, 80^{\circ} \mathrm{C}$ ) and extracted [hexane/tert-butyl methyl ether $(1: 1, \mathrm{v} / \mathrm{v})$ ] as described in detail by Osterhout et al. (1991). Fatty acid methyl esters were analysed by GC. Separation of fatty acid methyl esters was achieved using fused-silica capillary column (25 $\mathrm{m} \times 0.2 \mathrm{~mm}$ ) with cross-linked $5 \%$ phenyl methyl silicone (film thickness $0.33 \mu \mathrm{m}$; HP Ultra 2). The computercontrolled parameters were the same as those described by Osterhout et al. (1991). The instrument was equipped with a flame-ionization detector and an autosampler. $\mathrm{H}_{2}$ served as the carrier gas.

Polar lipid fatty acid analysis. Lipids were extracted using a modified Bligh-Dyer procedure (Bligh \& Dyer, 1959) as described previously (Vancanneyt et al., 1996).

Desorption chemical ionization (DCl) mass spectrometry. The DCI spectra were performed in positive mode with a double focussing mass spectrometer (Finnigan MAT-95) with an acceleration voltage of $5 \mathrm{kV}$ and a resolution of $1: 2300$. The ionization was carried out using ammonia as the reactant gas with a source pressure of $10^{-4} \mathrm{mbar}, 120 \mathrm{eV}$ ionization energy and a source temperature of $100{ }^{\circ} \mathrm{C}$. The single scans were acquired by scanning the magnet from $\mathrm{m} / \mathrm{z} 100$ to 1000 with a scan speed of $1.5 \mathrm{~s}$ (mass decade) $)^{-1}$ and a heating rate of $488^{\circ} \mathrm{C} \mathrm{min}^{-1}$ using an ICIS data system for recording the analysis.

Fast atom bombardment (FAB) mass spectrometry. FAB-MS in the positive and negative mode was performed on the first of two mass spectrometers of a tandem high-resolution instrument in a $E_{1} B_{1} E_{2} B_{2}$ configuration (JMS-HX/HX110A; JEOL) at $10 \mathrm{kV}$ accelerating voltage with the resolution set to $1: 1000$. The JEOL FAB gun was operated at $6 \mathrm{kV}$ with xenon. 3Nitrobenzyl alcohol was used as matrix in the positive mode and a mixture of triethanolamine and tetramethylurea (Japanese matrix) was used in the negative mode.

${ }^{1} \mathrm{H}$-NMR spectra were recorded in $7: 3 \mathrm{~d}$-chloroform $/ \mathrm{d}_{3}-$ methanol at $300 \mathrm{~K}$ on a Bruker ARX-400 NMR spectrometer relative to internal tetramethylsilane.

Respiratory lipoquinone analysis. Strains used for respiratory lipoquinone analysis were $B$. diminuta DSM $7234^{\mathrm{T}}$, Brevundimonas vesicularis DSM $7226^{\mathrm{T}}$, Caulobacter bacteroides DSM 4726 ${ }^{\mathrm{T}}$ (= ATCC 15254 $\mathrm{T}$ ), C. crescentus DSM $4727^{\mathrm{T}}$ (= ATCC $\left.15252^{\mathrm{T}}\right)$, Caulobacter fusiformis DSM $4728^{\mathrm{T}}\left(=\mathrm{ATCC} 15257^{\mathrm{T}}\right)$, C. halobacteroides DSM $4729^{\mathrm{T}}(=$ ATCC $\left.15269^{\mathrm{T}}\right)$, Caulobacter henricii DSM $4730^{\mathrm{T}}(=\mathrm{ATCC}$ $15253^{\mathrm{T}}$ ), C. henricii DSM 4731 (= ATCC 15266), Caulobacter intermedius DSM 4732 ${ }^{\mathrm{T}}\left(=\mathrm{ATCC} 15262^{\mathrm{T}}\right)$, Caulobacter leidyia DSM $4733^{\mathrm{T}}$ (= ATCC $15260^{\mathrm{T}}$ ), C. maris DSM $4734^{\mathrm{T}}$ (= ATCC $\left.15268^{\mathrm{T}}\right)$, C. subvibrioides DSM 4735 $5^{\mathrm{T}}(=$ ATCC 15264 ${ }^{\mathrm{T}}$ ), C. subvibrioides DSM 4736 (= ATCC 15265), C. variabilis DSM 4737 $(=$ ATCC 15255), $C$. vibrioides DSM $9893^{\mathrm{T}}\left(=\mathrm{CB} 51^{\mathrm{T}}\right.$; from J.T. Staley), $C$. vibrioides VKM B-1496 ${ }^{\mathrm{T}}$ (= CB51 ${ }^{\mathrm{T}}$; from M. Vainhstein), C. vibrioides DSM 4738 (= ATCC 11764), Caulobacter sp. DSM 6811 (=ATCC 15256), Caulobacter sp. DSM 6812(= ATCC 15267), Caulobacter sp. DSM 10556 (= ATCC 15263), Caulobacter sp. DSM 10560 (= ATCC 15259), Caulobacter sp. DSM 10670 (= ATCC 15258), Mycoplana bullata DSM $7126^{\mathrm{T}}$ and Mycoplana segnis DSM $7131^{\mathrm{T}}$.

Respiratory lipoquinones were extracted from $100 \mathrm{mg}$ freeze-dried cell material using the method described by Tindall (1990a, b), in which methanol: hexane was used for extraction and recovery of the respiratory lipoquinones. Respiratory lipoquinones were separated into their different classes (menaquinones and ubiquinones) by TLC on silica gel (Macherey-Nagel), using hexane: tert-butyl methyl ether $(9: 1, \mathrm{v} / \mathrm{v})$ as solvent. UV-absorbing bands corresponding to menaquinones or ubiquinones were removed from the plate and further analysed by HPLC. This step was carried out on an LDC Analytical (Thermo Separation Products) HPLC fitted with a reverse phase column (Macherey-Nagel; $2 \times 125 \mathrm{~mm}, 3 \mu \mathrm{m}, \mathrm{RP} 18)$ using methanol as the eluant. Respiratory lipoquinones were detected at $269 \mathrm{~nm}$.

Phenotypic characterization. Type strains and selected isolates were grown in $20 \mathrm{ml}$ PYEM medium amended with 0 , $5,10,20,30,40,60,80$ or $100 \mathrm{~g} \mathrm{NaCl}^{-1}$. The $\mathrm{OD}_{600}$ of the cell suspension was set to 0.3 at the beginning of the experiment and determined at time intervals over $2 \mathrm{~d}$. The differences between these measurements were used to determine salt tolerances.

Preparation of whole-cell lysates and the $\mathbf{4 3} \mathrm{kDa}$ protein. The protocol for the outer-membrane protein purification (Filip et al., 1973; Judd, 1988) was used with modifications as follows. A $50 \mathrm{ml}$ culture of bacteria was grown to an 


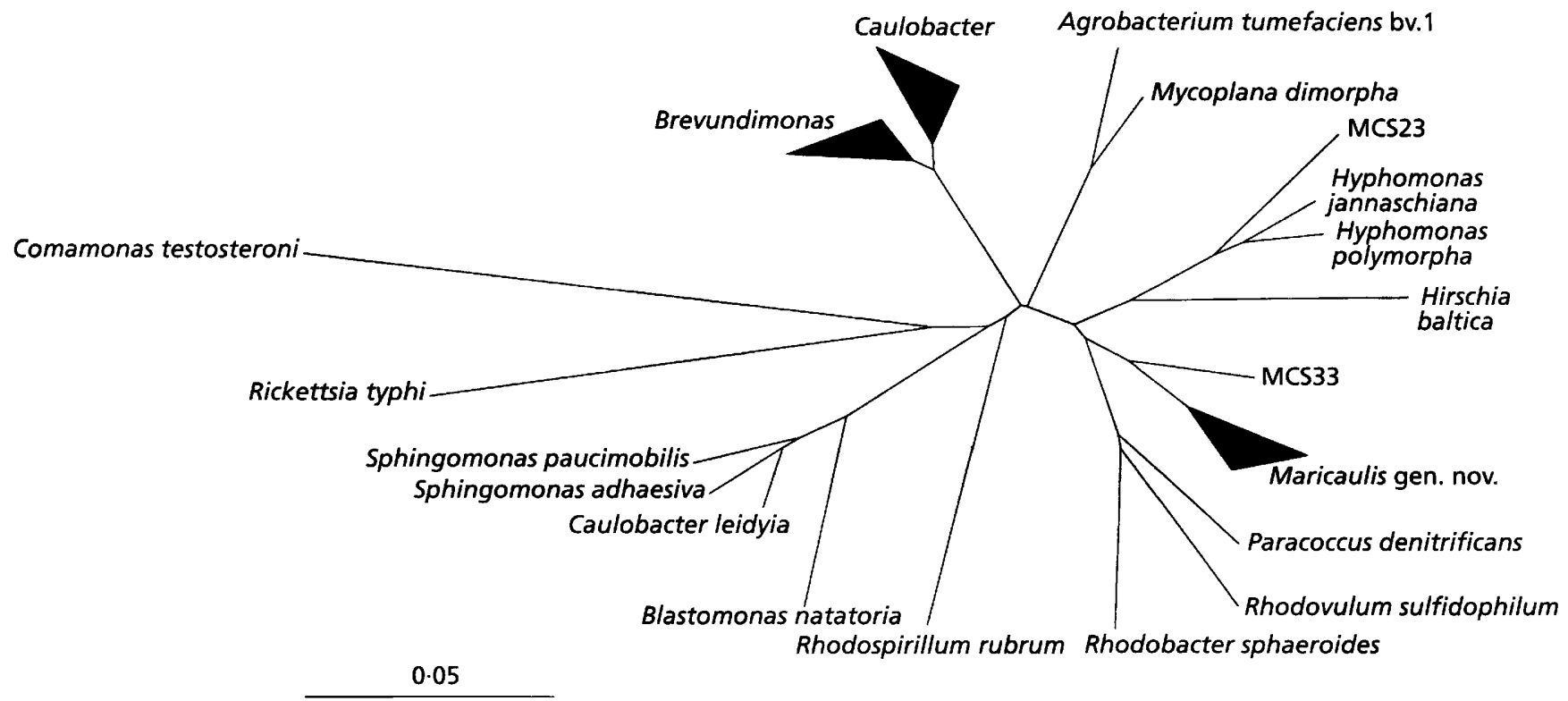

Fig. 1. Unrooted dendrogram based on a comparison of 16S rDNA sequences of strains belonging to Caulobacter sensu lato, Brevundimonas, Hyphomonas and Mycoplana within the context of the $\alpha$-lineage of the Proteobacteria. The cluster length is depicted as the estimated length of the longest branch within each cluster. Sequence data for strains of other genera were obtained from the GenBank/EMBL and/or RDP databases under the following accession numbers: Rickettsia typhi str. Wilmington (L36221), Blastomonas natatoria ATCC 35951 ${ }^{\top}$ (X73043), Sphingomonas paucimobilis DSM 1098 (X72722), Sphingomonas adhaesiva JCM $7370^{\top}$ (X72720), Rhodospirillum rubrum str. ATH 1.1.1. (RDP), Agrobacterium tumefaciens bv.1 NCPPB2437 (D14500), Hirschia baltica IFAM 1418 ${ }^{\top}$ (X52909), Rhodobacter sphaeroides IL106 (D16424), Paracoccus denitrificans LMG 4218 ${ }^{\top}$ (X69159), Mycoplana dimorpha ATCC 4279 ${ }^{\top}$ (D12786), Mycoplana bullata IAM $13153^{\top}$ (D12785), Mycoplana segnis IFO $13240^{\top}$ (D13947). Comamonas testosteroni (RDP) was included as an outgroup. Scale bar, 5 nucleotide substitution per 100 bases.

$\mathrm{OD}_{600}$ of 1.0 and washed three times in PBS $(137 \mathrm{mM} \mathrm{NaCl}$, $2 \cdot 7 \mathrm{mM} \mathrm{KCl}, 8 \mathrm{mM} \mathrm{Na}_{2} \mathrm{HPO}_{4}, 1.4 \mathrm{mM} \mathrm{KH}_{2} \mathrm{PO}_{4}$ adjusted to $\mathrm{pH} 7.4$ ) and the resulting pellet was resuspended in $4.5 \mathrm{ml}$ buffer A (10 mM Tris/ $\mathrm{HCl}, \mathrm{pH} 7 \cdot 5 ; 5 \mathrm{mM} \mathrm{MgCl})$. The cells were disrupted twice in a French press according to the supplier's instructions and cell debris was removed by a short low-speed centrifugation $(2000 \mathrm{~g})$. To prepare outer membranes, the whole cell lysate was centrifuged at $15000 \mathrm{~g}$ for $30 \mathrm{~min}$ at $4{ }^{\circ} \mathrm{C}$. The pellet was resuspended in $0.5 \mathrm{ml}$ buffer A and sodium lauroyl sarcosinate (Sarkosyl; Serva) added to a final concentration of $2 \%$. Incubation was carried out for $20 \mathrm{~min}$ at $20^{\circ} \mathrm{C}$, followed by another centrifugation step at $15000 \mathrm{~g}$ for $30 \mathrm{~min}$ at $20^{\circ} \mathrm{C}$. The supernatant fluid was discarded and the pellet was dissolved in double-concentration sample buffer. Samples were subjected to analytical SDS-PAGE [12\% (w/v) acrylamide] according to a standard protocol (Maizel, 1969).

Immunoblotting. Bacterial cells $(1 \mathrm{ml})$ with an $\mathrm{OD}_{600}$ of $0 \cdot 8$ were harvested by centrifugation at $6000 \mathrm{~g}$ for $5 \mathrm{~min}$ at $4{ }^{\circ} \mathrm{C}$ and dissolved in $100 \mu 1$ double-concentration SDS-PAGE sample buffer (Laemmli, 1970), boiled and subjected to SDS-PAGE $(12.5 \%)$. To avoid different mobilities of proteins due to sensitivity to 2-mercaptoethanol and heat (Hancock \& Carey, 1979), samples were boiled for $5 \mathrm{~min}$ before electrophoresis. The resulting protein profiles were highly reproducible. Immunoblots were carried out as described previously (Towbin et al., 1979; Tesar \& Marquardt, 1990). Nitrocellulose membranes were blocked in $5 \%$ non-fat dry milk (NFM) for $1 \mathrm{~h}$ at room temperature followed by incubation $(1 \mathrm{~h})$ with rabbit immune serum, diluted 1:500 in PBS and supplemented with 2.5\% NFM.
After washing the membranes three times in PBST (PBS containing $0.05 \%$ Tween) for $30 \mathrm{~min}$, peroxidaseconjugated goat anti-rabbit antibodies $(1: 1500$; Dianova $)$ in PBST were added and incubation of the membrane continued for $1 \mathrm{~h}$ at room temperature. Final washing was carried out with PBST followed by short incubation in PBS. Blots were developed by the addition of $2.2 \mathrm{mM} 4$-chloro-1naphthol and $0.03 \%(\mathrm{v} / \mathrm{v}) \mathrm{H}_{2} \mathrm{O}_{2}$ in $20 \mathrm{mM}$ Tris/ $\mathrm{HCl}(\mathrm{pH}$ 7.5).

Preparation of polyclonal sera. C. henricii ATCC $15253^{\mathrm{T}}, B$. vesicularis LMG $2350^{\mathrm{T}}$ and $C$. maris ATCC $15268^{\mathrm{T}}$ were grown to $\mathrm{OD}_{600}$ of $0 \cdot 3$, washed three times in PBS, fixed in PBS with $2 \%$ formaldehyde, washed again three times in PBS, aliquoted and stored at $-70^{\circ} \mathrm{C}$. A $1 \mathrm{ml}$ aliquot corresponding to an $\mathrm{OD}_{600}$ of $0 \cdot 3$ was mixed with an equal volume of incomplete Freund's adjuvant (Sigma) and the emulsion was injected subcutaneously into a female rabbit. Four booster injections were given at intervals of 3 weeks and the animal was bled after 15 weeks (Harlow \& Lane, 1988).

\section{RESULTS}

\section{$16 S$ rRNA gene sequences}

The 16S rDNA sequences of 62 strains described as species of the genus Caulobacter have been determined and analysed and three phylogenetic clusters were distinguished (Fig. 1). Three of the described species of Caulobacter ( $C$. crescentus, $C$. fusiformis and $C$. henricii), all of them isolated originally from fresh- 


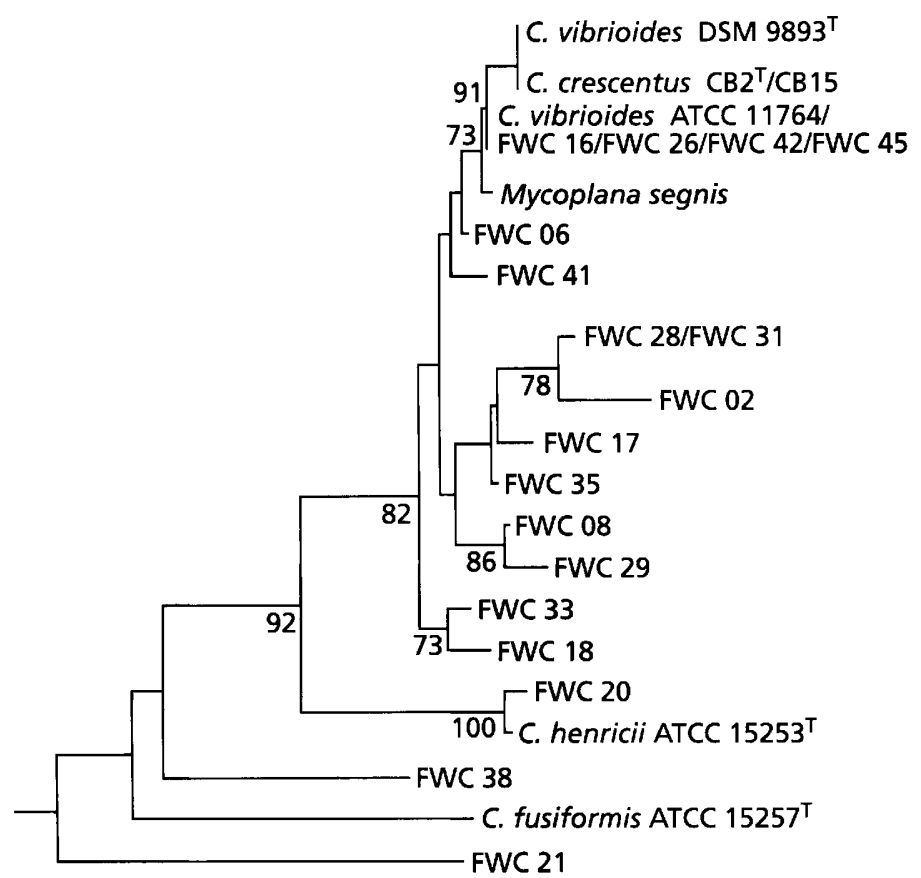

$1.0 \%$
Fig. 2. Phylogenetic tree based on a comparison of 165 rDNA sequences of strains belonging to Caulobacter sensu stricto. The dendrogram was generated with the neighbour-joining algorithm of the PHYLIP package. The data set was resampled 100 times to obtain bootstrap values of confidence. Bootstrap proportions of confidence are shown for those branchings with values of more than $70 \%$.

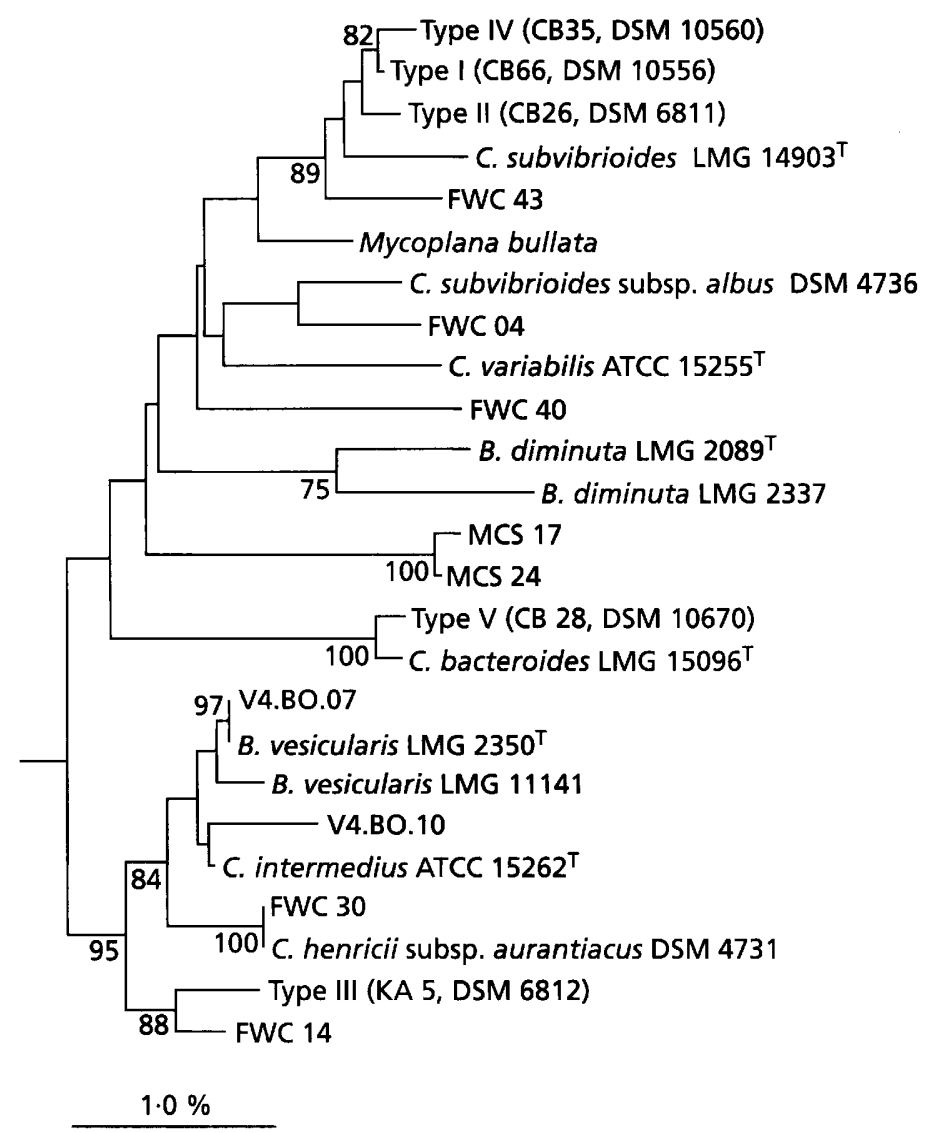

Fig. 3. Phylogenetic tree based on a comparison of the 16S rDNA sequences of strains belonging to Brevundimonas. For details see Fig. 2. water, formed a monophyletic cluster with the type species of the genus, $C$. vibrioides. The $16 \mathrm{~S}$ rDNA sequences of $C$. vibrioides, $C$. crescentus and a large number of freshwater isolates in this phylogenetic cluster, as well as Mycoplana segnis, were $99 \%$ or more similar to each other, forming the ' $C$. vibrioides- 
Table 2. Similarity table (\%) of $16 \mathrm{~S}$ rDNA sequences of Brevundimonas (B) and Caulobacter (C) type strains

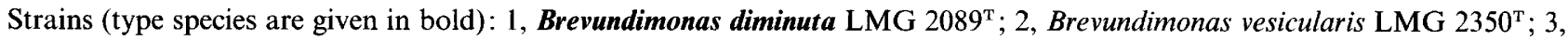
Brevundimonas bacteroides LMG $15096^{\mathrm{T}} ; 4$, Brevundimonas aurantiaca comb. nov. DSM 4731 ${ }^{\mathrm{T}} ; 5$, Brevundimonas intermedia comb. nov. ATCC $15262^{\mathrm{T}} ; 6$, Brevundimonas subvibrioides comb. nov. LMG $14903^{\mathrm{T}} ; 7$, Brevundimonas alba comb. nov. ATCC $15265^{\mathrm{T}} ; 8$, Brevundimonas variabilis comb. nov. ATCC $15255^{\mathrm{T}} ; 9$, Mycoplana bullata DSM $7126^{\mathrm{T}} ; 10$, Caulobacter vibrioides

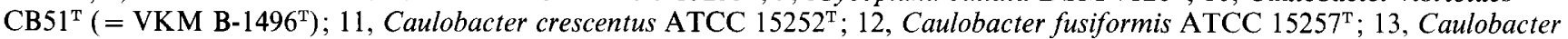
henricii ATCC $15253^{\mathrm{T}}$; 14, Caulobacter vibrioides ATCC 11764; 15, Caulobacter segnis comb. nov. DSM $7131^{\mathrm{T}}$.

\begin{tabular}{|lcccccccccccccc|c|}
\hline Genus & Strain & $\mathbf{1}$ & $\mathbf{2}$ & $\mathbf{3}$ & $\mathbf{4}$ & $\mathbf{5}$ & $\mathbf{6}$ & $\mathbf{7}$ & $\mathbf{8}$ & $\mathbf{9}$ & $\mathbf{1 0}$ & $\mathbf{1 1}$ & $\mathbf{1 2}$ & $\mathbf{1 3}$ & $\mathbf{1 4}$ \\
\hline B & 1 & $100 \cdot 0$ & & & & & & & & & & & & \\
B & 2 & $97 \cdot 0$ & $100 \cdot 0$ & & & & & & & & & & & \\
B & 3 & $95 \cdot 6$ & $97 \cdot 6$ & $100 \cdot 0$ & & & & & & & & & & \\
B & 4 & $96 \cdot 7$ & $99 \cdot 2$ & $97 \cdot 4$ & $100 \cdot 0$ & & & & & & & & & \\
B & 5 & $97 \cdot 1$ & $99 \cdot 9$ & $97 \cdot 7$ & $99 \cdot 2$ & $100 \cdot 0$ & & & & & & & & \\
B & 6 & $96 \cdot 8$ & $97 \cdot 3$ & $96 \cdot 2$ & $96 \cdot 8$ & $97 \cdot 4$ & $100 \cdot 0$ & & & & & & & \\
B & 7 & $95 \cdot 9$ & $98 \cdot 0$ & $97 \cdot 2$ & $97 \cdot 9$ & $98 \cdot 1$ & $97 \cdot 8$ & 100.0 & & & & & & \\
B & 8 & $95 \cdot 9$ & $97 \cdot 2$ & $97 \cdot 9$ & $96 \cdot 8$ & $97 \cdot 2$ & $98 \cdot 0$ & 98.1 & $100 \cdot 0$ & & & & & \\
B & 9 & $98 \cdot 2$ & $98 \cdot 0$ & $96 \cdot 8$ & $97 \cdot 7$ & $98 \cdot 1$ & $98 \cdot 3$ & 97.4 & $97 \cdot 5$ & $100 \cdot 0$ & & & & \\
C & 10 & $93 \cdot 7$ & $94 \cdot 9$ & $93 \cdot 5$ & $94 \cdot 9$ & $95 \cdot 0$ & $93 \cdot 5$ & 93.6 & $93 \cdot 4$ & $93 \cdot 7$ & $100 \cdot 0$ & & & \\
C & 11 & $93 \cdot 7$ & & & & & & & & & $100 \cdot 0$ & $100 \cdot 0$ & & \\
C & 12 & $94 \cdot 3$ & & & & & & & & & $96 \cdot 5$ & $96 \cdot 5$ & $100 \cdot 0$ & \\
C & 13 & $93 \cdot 5$ & & & & & & & & & $97 \cdot 6$ & $97 \cdot 6$ & $96 \cdot 3$ & $100 \cdot 0$ & \\
C & 14 & $93 \cdot 9$ & & & & & & & & & $99 \cdot 8$ & $99 \cdot 8$ & $96 \cdot 7$ & $97 \cdot 8$ & $100 \cdot 0$ \\
C & 15 & $93 \cdot 8$ & & & & & & & & & $99 \cdot 8$ & $99 \cdot 8$ & $96 \cdot 7$ & $97 \cdot 9$ & $99 \cdot 9$ \\
\hline
\end{tabular}

assemblage' or '-lineage' (Fig. 2). Considering the $16 \mathrm{~S}$ rDNA sequence data alone, these organisms, conceivably, could be assigned to a single species, although higher resolution methods, such as PCR typing, enable one to recognize distinct subclusters and to further resolve the assemblage. The $16 \mathrm{~S}$ rDNA sequence data suggest that $C$. crescentus is synonymous with $C$. vibrioides, as the type strains of these species possessed identical 16S rRNA gene sequences.

C. henricii formed a distinct phylogenetic branch (Fig. 2 ), together with isolate FWC 20 , which is yellow pigmented like $C$. henricii and probably represents another strain of $C$. henricii.

C. fusiformis comprised another distinct branch outside the ' $C$. vibrioides-assemblage' (Fig. 2), as did the freshwater isolates FWC 21 and FWC 38, both representing as yet undescribed species. An important note is that the 16S rDNA sequence determined for $C$. fusiformis (ATCC $15257^{\mathrm{T}}$ ) in this study was identical to the sequence published previously (Stahl et al., 1992) for strain ' $\mathrm{CB} 7$ ', i.e. the type strain of $C$. bacteroides. The $16 \mathrm{~S}$ rDNA sequence determined in this study for C. bacteroides (LMG $15096^{\mathrm{T}}$ ) clustered with those of species of the genus Brevundimonas.

The 16S rDNA sequences of four described species classified as Caulobacter ( $C$. bacteroides, $C$. intermedius, $C$. subvibrioides and $C$. variabilis) clustered with those of the described species of Brevundimonas. $B$. diminuta and $B$. vesicularis formed distinct lineages within the cluster (Fig. 3). The 16S rDNA sequence data demonstrated that $B$. diminuta strain LMG 2337 is distinct from the type strain of $B$. diminuta and probably represents a new species of Brevundimonas. $C$. bacteroides, $C$. subvibrioides and $C$. variabilis fall within the Brevundimonas phylogenetic cluster, with 16S rDNA sequence similarity values of $93 \cdot 5,93.5$ and $93.4 \%$, respectively, to $C$. vibrioides, the type species of the genus Caulobacter. The 16S rDNA sequence of $C$. intermedius was $95 \%$ similar to that of $C$. vibrioides but was $99 \cdot 2 \%$ similar to the $16 \mathrm{~S}$ rDNA sequence of $B$. vesicularis (Table 2). Clearly, in light of these data, $C$. bacteroides, $C$. intermedius, $C$. subvibrioides and $C$. variabilis cannot be considered to be species of Caulobacter.

Isolates MCS 17 and MCS 24, with 99.8\% 16S rDNA sequence similarity, formed a distinct branch within the Brevundimonas cluster, representing a novel species of the genus. Further, on the basis of the 16S rDNA sequence data, strains FWC 04, FWC 40 and FWC 43 may all represent new species. $C$. henricii subsp. aurantiacus together with isolate FWC 30, which both have identical 16S rDNA sequences and are yellow pigmented, possess a high similarity to the $16 \mathrm{~S}$ rDNA sequence of $B$. vesicularis, but form a distinct branch. They may represent another species of Brevundimonas. The $16 \mathrm{~S}$ rDNA sequence data revealed that $C$. subvibrioides subsp. albus is phylogenetically too divergent to represent a subspecies of $C$. subvibrioides, as the dissimilarity of the 16S rDNA sequences of these strains was $2.2 \%$, supporting the DNA-DNA hybridization data (Moore et al., 1978).

The organisms denoted as Types $\mathbf{I}-\mathbf{V}$ have been 


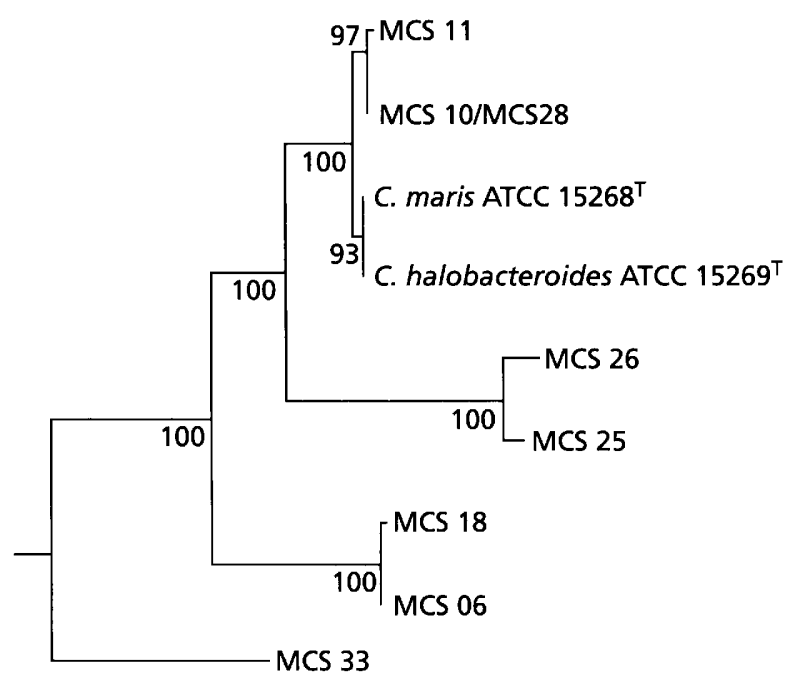

$1.0 \%$

Fig. 4. Phylogenetic tree based on a comparison of the $16 \mathrm{~S}$ rDNA sequences of strains belonging to Maricaulis gen. nov. For details see Fig. 2.

characterized by Poindexter (1964) and were distinct from the Caulobacter species described in that publication, although no species epithet was assigned to these organisms. The five representatives of the respective Types I-V deposited in public strain collections clustered phylogenetically with the species of Brevundimonas.

The marine species of Caulobacter, $C$. maris and $C$. halobacteroides, were observed to form a distinct phylogenetic cluster (i.e. Maricaulis gen. nov.), including seven of the MCS isolates (Fig. 4). Phylogenetically, these organisms were more related to species of the genus Hyphomonas than to species of Caulobacter sensu stricto. The 16S rDNA sequences of C. maris and C. halobacteroides were identical and very similar to the sequences of isolates MCS 10, MCS 11 and MCS 28. Marine isolates MCS 25 and MCS 26, on the one hand, and MCS 6 and MCS 18, on the other hand, formed pairs composed of closely related strains with high 16S rDNA sequence similarities, indicating that they may represent two additional species of Maricaulis gen. nov.

The 16S rDNA sequence of MCS 33 revealed a similarity of only $94.2 \%$ to that of $C$. maris, possibly identifying it as a member of a separate, undescribed genus. The $16 \mathrm{~S}$ rDNA sequence of strain MCS $23 \mathrm{had}$ similarity values of $88.4 \%$ to the sequence of C. maris, $86.1 \%$ to the sequence of $C$. vibrioides and $90.4 \%$ to the sequence of Hyphomonas polymorpha. These levels of $16 \mathrm{~S}$ rDNA sequence similarity indicate that strain MCS 23 represents a distinct phylogenetic lineage separate from any described species. MCS 23 is more related to species of Hyphomonas than to Maricaulis gen. nov. and probably represents a member of yet another new genus.

The 16S rDNA sequence of $C$. leidyia did not group with any of the three phylogenetic clusters described above. While the similarity of the $16 \mathrm{~S}$ rDNA sequence of $C$. leidyia to that of $C$. vibrioides was only $86.9 \%, C$. leidyia had $94.9 \% 16 \mathrm{~S}$ rDNA sequence similarity to Sphingomonas paucimobilis, the type species of the genus, and was most similar $(96.7 \%)$ to the $16 \mathrm{~S}$ rDNA sequence of Sphingomonas adhaesiva. Therefore, on the basis of 16S rDNA sequence analysis of this study, $C$. leidyia may be recognized as a species of the genus Sphingomonas, which is also a genus within the $\alpha$ subclass of the Proteobacteria, but phylogenetically distinct from Caulobacter. The 16S rDNA sequence for C. leidyia determined in this study was identical to that (GenBank accession no. M83797) described as being from $C$. subvibrioides strain CB8 $1^{\mathrm{T}}$ (Stahl et al., 1992). However, from the data obtained in this study, the 16S rDNA sequence of $C$. subvibrioides (LMG $14903^{\mathrm{T}}=\mathrm{ATCC} \quad 15264^{\mathrm{T}}=\mathrm{CB} 81^{\mathrm{T}}$ ) was clearly different from the sequence reported by Stahl et al. (1992) and, in an independent study, Sly et al. (1997) also recognized that the $16 \mathrm{~S} \mathrm{rDNA}$ sequence for $C$. subvibrioides $\left(\mathrm{ATCC} 15264^{\mathrm{T}}=\mathrm{ACM} 2483^{\mathrm{T}}=\mathrm{CB} 81^{\mathrm{T}}\right.$ ) is different from that published by Stahl et al. (1992). The sequence determined in this study for $C$. subvibrioides was identical with that determined by Sly et al. (1997).

\section{Analysis of 16S-23S ISR}

The 16S-23S rDNA ISR has been used as a rapid typing tool for differentiating closely related Caulobacter species and isolates. For this purpose, primers complementary to highly conserved regions in the $3^{\prime}$ part of the 16S rRNA gene (the forward primer) and the $5^{\prime}$ part of the 23S rRNA gene (the reverse primer) were used for PCR amplification. The reference strains and isolates analysed possessed differences, as demonstrated by electrophoretic mobilities, primarily in the lengths of the PCR-amplified ISR (Fig. 5a). All strains of Caulobacter species displayed a PCR product of a single high-molecular-mass band ranging in size from $1.4 \mathrm{~kb}(C$. vibrioides ATCC 11764$)$ to $1.8 \mathrm{~kb}(C$. maris ATCC $15266^{\mathrm{T}}$ and $C$. halobacteroides ATCC $15269^{\mathrm{T}}$ ), with approximately $0.6 \mathrm{~kb}$ corresponding to the $3^{\prime}$ part of the $16 \mathrm{~S}$ rDNA, nearly $0.5 \mathrm{~kb}$ corresponding to the $5^{\prime}$ part of the $23 \mathrm{~S}$ rDNA, and the difference, $0.3-0.7 \mathrm{~kb}$, comprising the $16 \mathrm{~S}-23 \mathrm{~S}$ rDNA ISR.

Differences in the sizes of PCR-amplified ISR products allowed the differentiation of the marine species, $C$. maris and $C$. halobacteroides, as one type, from the organisms comprising closely related (by $16 \mathrm{~S}$ rDNA sequence comparisons) organisms clustering around the type strain of $C$. vibrioides (Fig. 2). Further, a higher-resolution approach, comprising the fingerprint analysis of fragments from restriction digestion of the ISR PCR products, supported the typing of the strains, 

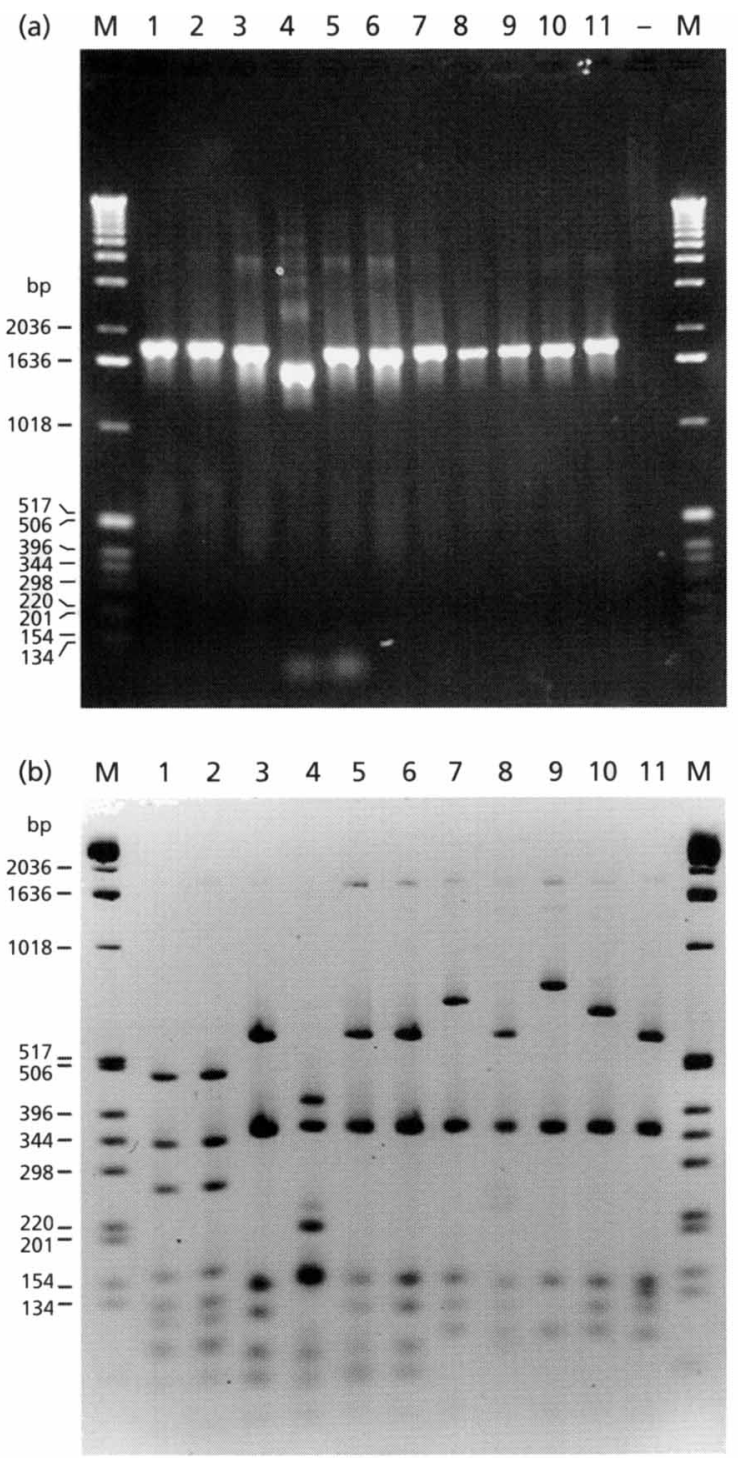

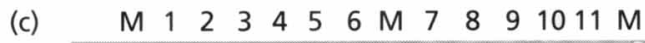

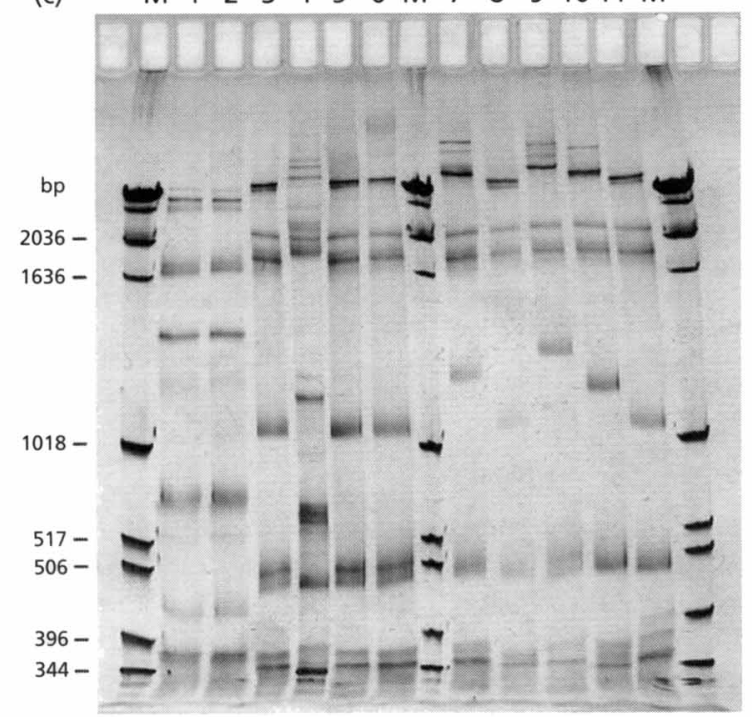

as defined by the size differentiation of the ISR PCR products. After TaqI digestion, ISR fingerprints of higher complexity were obtained, as expected (Fig. $5 \mathrm{~b}$ ). The ISR PCR products of the type strains of $C$. maris and $C$. halobacteroides produced exactly the same pattern after TaqI digestion and were easily distinguishable from the other strains. $C$. vibrioides DSM $9893^{\mathrm{T}}$ (as well as VKM B-1496 ${ }^{\mathrm{T}}$ ) and $C$. crescentus $\mathrm{CB} 2^{\mathrm{T}}$ also exhibited an identical ISR TaqI fingerprint pattern, while variations in the fingerprints of the other strains were observed, mainly at the highest molecular mass bands. These high-molecularmass ISR restriction bands of $C$. vibrioides DSM $9893^{\mathrm{T}}$ (and also VKM B-1496 ${ }^{\mathrm{T}}$ ), C. crescentus $\mathrm{CB} 2^{\mathrm{T}}$ and isolates FWC 16 and FWC 45 possessed identical mobilities while $C$. crescentus $\mathrm{CB} 15$ and isolates FWC 26 and FWC 42 possessed high-molecular-mass ISR restriction bands, in each case, of unique electrophoretic mobility. A common ISR restriction band of $0 \cdot 3-0.4 \mathrm{~kb}$ was observed in all strains of $C$. vibrioides, C. crescentus and FWC isolates analysed and was absent in the marine strains of $C$. maris and $C$. halobacteroides. Although C. vibrioides ATCC 11764 was observed to possess an overall ISR fingerprint pattern different from all other strains, it did share two bands common to all strains of $C$. vibrioides, $C$. crescentus and FWC isolates analysed.

Finally, SSCP analysis was applied to the TaqI restriction fragments. Under the conditions described in the Methods, no additional distinctions were detected between strains of the same types, as defined by the sizes of ISR PCR products and by TaqI restriction patterns of ISR PCR products, (Fig. 5c), indicating that no microheterogeneity exists in the nucleotide sequences of the respective fragments.

\section{DNA-DNA hybridization}

Because identical 16S rDNA sequences were determined for $C$. maris and $C$. halobacteroides and no differences in the ISR region of these species were found, DNA-DNA hybridizations between C. maris ATCC $15268^{\mathrm{T}}$ and $C$. halobacteroides ATCC $15269^{\mathrm{T}}$ were performed in triplicate. For both type strains, a DNA binding value of $92 \%$ was found.

Fig. 5. (a) Fingerprints generated by ISR-PCR of Caulobacter strains and new isolates in $1.5 \%$ agarose gels. (b) Taql restriction analysis of PCR-amplified ISR of the different strains in $3.0 \%$ agarose gels. (c) SSCP gel of the PCR-amplified ISR after digestion with Taql. Samples in all the gels were loaded as follows: 1, C. maris ATCC $15268^{\mathrm{T}} ; 2$, C. halobacteroides ATCC $15269^{\top} ; 3$, C. vibrioides DSM $9893^{\top} ; 4$, C. vibrioides ATCC 11764; 5. C. crescentus $\mathrm{CB2}^{\top} ; 6, C$ vibrioides VKM B-1496 ${ }^{\top} ; 7, C$. crescentus CB15; 8, Caulobacter sp. FWC 16; 9, Caulobacter sp. FWC 26; 10, Caulobacter sp. FWC 42; 11, Caulobacter sp. FWC 45. In (a), a negative control for ISR PCR amplification was included (-). M, 1 kb DNA ladder molecular mass marker (Gibco$B R L$ ). 


\section{Respiratory lipoquinones}

Examination of all strains listed for their respiratory lipoquinone composition indicated that only ubiquinones were present. Separation of the ubiquinones according to the length of the isoprenoid side-chain indicated that all organisms contained ubiquinone $(\mathrm{Q}-$ $10)$ as the major respiratory quinone.

\section{Phenotypic characterization}

Caulobacteria which cluster together by $16 \mathrm{~S}$ rDNA sequence analysis and lipid patterns showed similar salt tolerances (Fig. 6). Caulobacter crescentus, $C$. vibrioides and $C$. fusiformis showed reduced growth without salt, optimal growth with $5 \mathrm{~g} \mathrm{NaCl}^{-1}$ and no growth at salt concentrations of $10 \mathrm{~g} \mathrm{l}^{-1}$ or more (Fig. 6a). Contrary to these strains, the bacteria clustering around the type strains of Brevundimonas grew without salt, tolerated salt concentrations up to $20 \mathrm{~g}^{-1}$ and did not grow above $80 \mathrm{~g}$ salt $1^{-1}$. The diversity observed in the $16 \mathrm{~S}$ rDNA sequences and lipid data of the Brevundimonas cluster was mirrored in the tolerance to salt, resulting in a broad range of different tolerances of the individual species to salt concentrations between 20 and $80 \mathrm{~g} \mathrm{l}^{-1}$ (Fig. 6b). Species of Maricaulis gen. nov., on the other hand, showed no or only reduced growth without salt, reached their optimal growth rates between 20 and $80 \mathrm{~g}^{-1}$ and showed no or reduced growth at $100 \mathrm{~g}$ salt $\mathrm{l}^{-1}$ (Fig. 6c). This overall difference in salt tolerance was also observed with marine caulobacteria allowing identification of the isolates as Brevundimonas or Maricaulis gen. nov. Although Caulobacter maris and $C$. halobacteroides were differentiated in their description by their different tolerances to salt (Poindexter, 1964), we observed nearly identical salt tolerance.

Because the Brevundimonas strains and Mycoplana bullata and Mycoplana segnis were so different from Caulobacter spp. in terms of morphology but closely related in terms of molecular data, we looked for the presence of prosthecae. We grew $B$. diminuta LMG $2089^{\mathrm{T}}$ and Mycoplana bullata DSM $7126^{\mathrm{T}}$ in medium PYEM containing only 0.2 g peptone/yeast extract $1^{-1}$. Neither species developed prosthecae, whether grown in PYEM medium or in this modified PYEM medium.

\section{Analysis of fatty acid methyl esters}

The cellular fatty acid compositions of Caulobacter type strains and type strains of phylogenetically related taxa are shown in Table 3 . The caulobacteria could be divided into four major groups. One, with Caulobacter subsp. sensu stricto, contained significant amounts of the fatty acids 12:13-OH, 14:0, 16:0, sum4 (Table 3), sum7 (Table 3) and ECL 18.080. All strains, except Mycoplana segnis, additionally contained ECL 11.798 , $15: 0,17: 0,17: 1 \omega 6 c$ and $17: 1 \omega 8 c$. Closely related to this group was the second group with Brevundimonas and related strains. Here, as in Caulobacter sensu stricto, 14:0 was present which was lacking in all other groups. The Brevundimonas group differed from all (a)

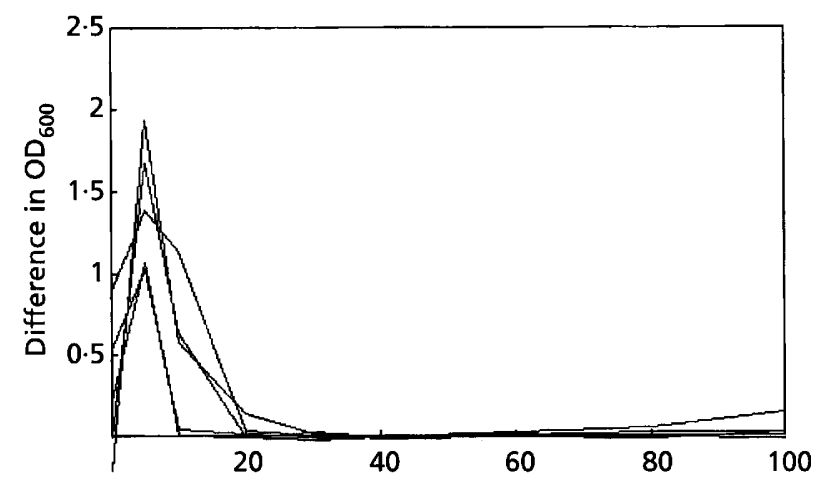

(b)

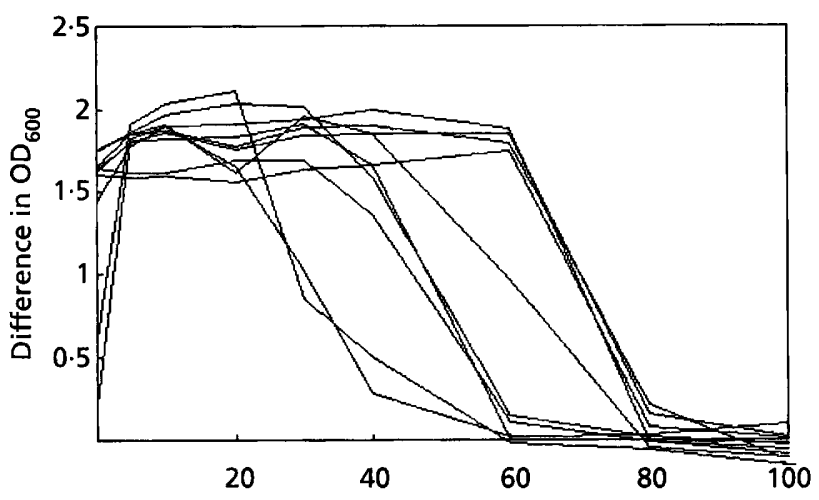

(c)

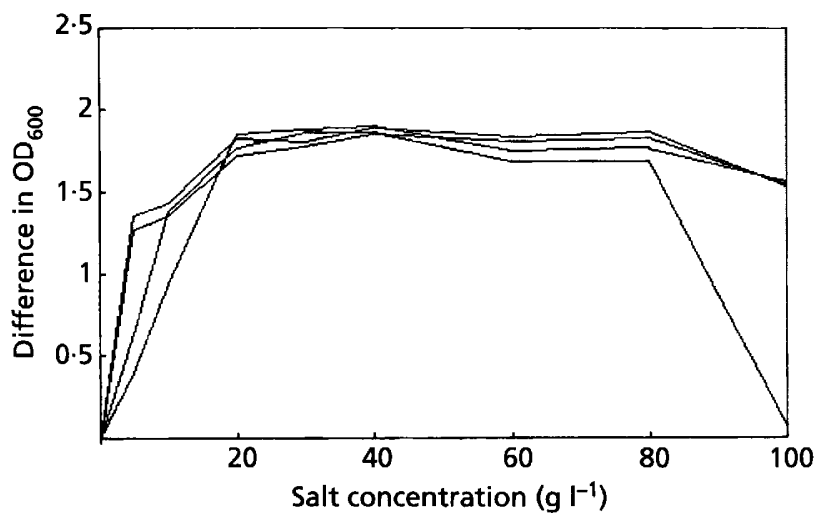

Fig. 6. Growth of strains of caulobacteria at different salt concentrations. (a) Growth of strains belonging to the genus Caulobacter sensu stricto. (b) Growth of type strains of Brevundimonas at different salt concentrations. Note the broad range of salt tolerances of the different species. (c) Growth of type strains and some isolates of Maricaulis gen. nov. at different salt concentrations.

other groups by the presence of an unidentified fatty acid at ECL 17.897. Fatty acids present in all Brevundimonas strains were 12:0 3-OH, 14:0, 15:0, 16:0, sum 4, 17:0, 17:1 $1 \omega 6 c, 17: 1 \omega 8 c$ and sum7. Brevundimonas strains are differentiated from Caulobacter strains by the absence of ECL 11.789 and by the presence of at least traces of ECL 17.897, only traces of 12:13-OH, higher amounts of 12:0 3-OH and by a 
Table 3. Fatty acid content (mean percentage of total) of whole-cell hydrolysates of Caulobacter strains

Only the fatty acids counting for more than $1.0 \%$ (mean amount) were indicated. The following strains contained significant amounts $\left(>1.0 \%\right.$ ) of additional fatty acids: $B$. diminuta LMG $2089^{\mathrm{T}}$ and LMG 2337 also contained $19: 0$ cyclow $1 \mathrm{c}(6 \cdot 2$ and $7 \cdot 4 \%$, respectively); $C$. leidyia ATCC $15260^{\mathrm{T}}$ also contained 16:0 2-OH (1.7\%) 18:1 $155 c(2 \cdot 4 \%)$ and 19:0cyclo $\omega 8 c(1 \cdot 5 \%) ; C$.

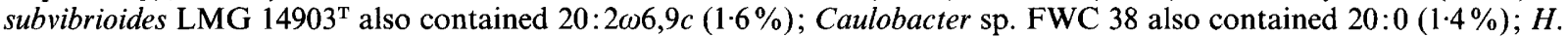
polymorpha DSM $2665^{\mathrm{T}}$ also contained sum9 (19:0cyclow10c and/or ECL 18.846 and/or ECL 18.858; $\left.4.5 \%\right) ;$ Mycoplana bullata

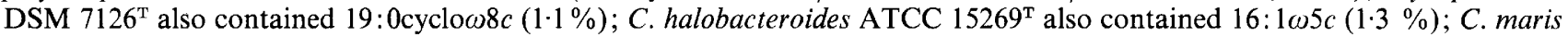
ATCC $15268^{\mathrm{T}}$ also contained $16: 1 \omega 9 c(1.0 \%)$; C. subvibrioides subsp. albus also contained ECL $15.275(2 \cdot 0 \%), 16: 1 \omega 9 c(2 \cdot 7 \%)$ and 19:0cyclow8c $(2 \cdot 4 \%)$; Mycoplana segnis LMG $17158^{\mathrm{T}}$ also contained ECL $18.140(6.9 \%)$. ECL, unidentified fatty acid with equivalent chain-length. Sum, Summed feature. Sum4 consisted of one or more of the following fatty acids which could not be

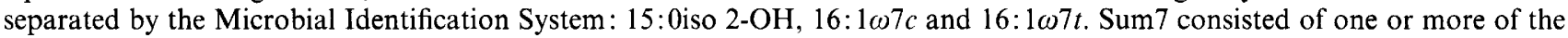
following fatty acids: $18: 1 \omega 7 c, 18: 1 \omega 9 t$ and $18: 1 \omega 12 t$. Strains: 1, C. bacteroides LMG $15096^{\mathrm{T}} ; 2$, C. henricii subsp. aurantiacus ATCC 15266 ${ }^{\mathrm{T}} ; 3$, C. intermedius ATCC $15262^{\mathrm{T}} ; 4$, C. subvibrioides LMG $14903^{\mathrm{T}} ; 5$, C. subvibrioides subsp. albus ATCC $15265^{\mathrm{T}}$; 6, C. variabilis ATCC $15255^{\mathrm{T}} ; 7, B$. vesicularis LMG $2350^{\mathrm{T}} ; 8$, B. diminuta LMG 2089 $;$, Mycoplana bullata DSM $7126^{\mathrm{T}} ; 10$, C. crescentus CB2 ${ }^{\mathrm{T}} ; 11$, C. fusiformis ATCC 15257 $;$; 12 , C. henricii ATCC $15253^{\mathrm{T}}$; 13, C. vibrioides ATCC 11764; 14, Mycoplana segnis LMG $17158^{\mathrm{T}} ; 15$, C. maris ATCC $15268^{\mathrm{T}} ; 16$, C. halobacteroides ATCC $15269^{\mathrm{T}} ; 17$, Caulobacter sp. FWC $38 ; 18, C$. leidyia ATCC $15260^{\mathrm{T}}$.

\begin{tabular}{|c|c|c|c|c|c|c|c|c|c|c|c|c|c|}
\hline Strain & Medium & 11: & o 3-OH & ECL 11.798 & $12: 0 \quad 1$ & 12:0 3-OH & 12:1 3-OH & I $14: 0$ & 14:0 2-OH & $15: 0$ & $16: 0$ & Sum4 & $\begin{array}{c}16: 12- \\
O H\end{array}$ \\
\hline \multicolumn{14}{|c|}{ Genus Brevundimonas } \\
\hline 1 & PYEM & & - & - & - & $2 \cdot 3$ & - & $3 \cdot 0$ & - & TR & $12 \cdot 8$ & $6 \cdot 7$ & - \\
\hline 2 & PYEM & & - & - & - & $2 \cdot 3$ & TR & $3 \cdot 4$ & - & $3 \cdot 0$ & $21 \cdot 3$ & $4 \cdot 0$ & - \\
\hline 3 & PYEM & & - & - & - & $1 \cdot 7$ & - & $1 \cdot 5$ & - & $2 \cdot 8$ & $24 \cdot 3$ & $7 \cdot 5$ & - \\
\hline 4 & PYEM & & - & - & - & $2 \cdot 8$ & - & $4 \cdot 6$ & - & $1 \cdot 5$ & $15 \cdot 9$ & $11 \cdot 2$ & - \\
\hline 5 & PYEM & & - & - & - & $1 \cdot 1$ & TR & 1.0 & - & $5 \cdot 4$ & $16 \cdot 8$ & 5.9 & - \\
\hline 6 & PYEM & & - & - & - & $2 \cdot 3$ & - & $2 \cdot 5$ & - & $5 \cdot 4$ & $13 \cdot 5$ & $6 \cdot 2$ & - \\
\hline 7 & PYEM & & - & - & - & 1.9 & - & $2 \cdot 4$ & - & $4 \cdot 0$ & $20 \cdot 7$ & $5 \cdot 1$ & - \\
\hline 8 & PYEM & & - & - & - & 1.5 & TR & $\mathrm{TR}$ & - & 7.6 & $10 \cdot 1$ & $1 \cdot 0$ & - \\
\hline 9 & PYEM & & - & - & - & $1 \cdot 3$ & TR & TR & - & $5 \cdot 1$ & 18.9 & $4 \cdot 5$ & - \\
\hline \multicolumn{14}{|c|}{ Genus Caulobacter sensu stricto } \\
\hline 10 & PYEM & & - & 1.4 & - & TR & $1 \cdot 0$ & 1.4 & TR & $13 \cdot 6$ & $13 \cdot 3$ & $8 \cdot 6$ & $6 \cdot 1$ \\
\hline 11 & PYEM & & - & TR & 1.9 & - & $2 \cdot 8$ & $1 \cdot 3$ & - & $13 \cdot 8$ & $11 \cdot 7$ & TR & - \\
\hline 12 & PYEM & & - & 1.8 & - & TR & $1 \cdot 2$ & 2.6 & - & $14 \cdot 9$ & $12 \cdot 7$ & $19 \cdot 3$ & - \\
\hline 13 & PYEM & & - & $2 \cdot 4$ & TR & TR & 1.6 & 1.5 & - & $7 \cdot 1$ & $15 \cdot 4$ & $14 \cdot 9$ & - \\
\hline 14 & PYEM & & - & - & $3 \cdot 5$ & $2 \cdot 4$ & $2 \cdot 7$ & 2.7 & - & - & $20 \cdot 2$ & $19 \cdot 7$ & $5 \cdot 0$ \\
\hline \multicolumn{14}{|c|}{ Genus Maricaulis } \\
\hline 15 & SPYEM & & 26 & - & - & - & - & - & - & TR & $17 \cdot 0$ & $6 \cdot 6$ & - \\
\hline 16 & SPYEM & & 3.8 & - & - & - & - & - & - & TR & $15 \cdot 6$ & $6 \cdot 0$ & - \\
\hline \multicolumn{14}{|c|}{ Ungrouped strains } \\
\hline $17^{\circ}$ & PYEM & & - & - & $2 \cdot 7$ & - & $3 \cdot 4$ & TR & - & $3 \cdot 9$ & $16 \cdot 5$ & TR & - \\
\hline 18 & PYEM & & - & - & - & - & - & - & $13 \cdot 3$ & - & $16 \cdot 6$ & - & - \\
\hline Strain & $17: 0$ & $\begin{array}{l}17: 1 \\
\omega 6 c\end{array}$ & $\begin{array}{l}17: 1 \\
\omega 8 c\end{array}$ & $\begin{array}{c}17: 0 \\
\text { iso }\end{array}$ & $\begin{array}{c}17: 1 \\
\text { iso } \omega 9 c\end{array}$ & $\begin{array}{c}\text { ECL } \\
\mathbf{1 7 . 8 9 7}\end{array}$ & 18:0 & Sum7 & $\begin{array}{l}18: 1 \\
\omega 9 c\end{array}$ & $\begin{array}{c}\text { ECL } \\
\mathbf{1 8 . 0 8 0}\end{array}$ & & $\begin{array}{l}\text { CL } \\
.424\end{array}$ & $\begin{array}{c}\text { ECL } \\
18.797\end{array}$ \\
\hline \multicolumn{14}{|c|}{ Genus Brevundimonas } \\
\hline 1 & TR & TR & $1 \cdot 4$ & - & - & TR & TR & $69 \cdot 4$ & - & TR & & - & - \\
\hline 2 & $1 \cdot 7$ & $1 \cdot 0$ & 1.6 & - & -- & $1 \cdot 3$ & $\mathrm{TR}$ & $56 \cdot 5$ & - & $3 \cdot 5$ & & - & - \\
\hline 3 & 1.6 & 1.1 & 2.0 & - & - & TR & TR & 49.4 & - & 6.3 & & - & - \\
\hline 4 & TR & TR & $1 \cdot 8$ & - & - & TR & $1 \cdot 4$ & $56 \cdot 7$ & - & TR & & - & - \\
\hline 5 & $2 \cdot 5$ & 1.5 & $7 \cdot 7$ & - & - & $1 \cdot 4$ & TR & $43 \cdot 2$ & $1 \cdot 0$ & $2 \cdot 7$ & & - & TR \\
\hline 6 & $2 \cdot 2$ & $2 \cdot 5$ & $5 \cdot 7$ & - & - & $\mathrm{TR}$ & TR & $55 \cdot 8$ & - & - & & - & $1 \cdot 0$ \\
\hline 7 & $2 \cdot 4$ & $1 \cdot 4$ & $2 \cdot 6$ & - & - & $1 \cdot 1$ & TR & $53 \cdot 7$ & - & $4 \cdot 5$ & & - & - \\
\hline 8 & $8 \cdot 5$ & $6 \cdot 2$ & $10 \cdot 8$ & - & - & $1 \cdot 1$ & TR & $38 \cdot 7$ & - & - & & - & $3 \cdot 1$ \\
\hline 9 & $1 \cdot 6$ & $1 \cdot 5$ & $3 \cdot 3$ & - & - & $1 \cdot 1$ & TR & $55 \cdot 5$ & - & 1.6 & & - & TR \\
\hline \multicolumn{14}{|c|}{ Genus Caulbacter sensu stricto } \\
\hline 10 & $6 \cdot 3$ & $4 \cdot 0$ & $4 \cdot 6$ & - & - & - & TR & $32 \cdot 3$ & - & 5.9 & & - & TR \\
\hline 11 & $7 \cdot 1$ & 8.9 & $4 \cdot 0$ & - & - & - & - & $42 \cdot 4$ & - & $4 \cdot 8$ & & - & - \\
\hline 12 & 1.6 & $3 \cdot 2$ & $5 \cdot 3$ & - & - & - & TR & $35 \cdot 7$ & - & $\mathrm{TR}$ & & - & - \\
\hline 13 & 1.9 & 1.6 & $2 \cdot 6$ & TR & TR & - & TR & $39 \cdot 9$ & - & $6 \cdot 3$ & & - & TR \\
\hline 14 & - & - & - & - & - & - & - & $35 \cdot 4$ & - & 1.5 & & - & - \\
\hline \multicolumn{14}{|c|}{ Genus Maricaulis } \\
\hline 15 & $5 \cdot 3$ & TR & $4 \cdot 0$ & $7 \cdot 7$ & $17 \cdot 4$ & - & $1 \cdot 1$ & $24 \cdot 5$ & $6 \cdot 4$ & 1.6 & & $1 \cdot 3$ & TR \\
\hline 16 & $6 \cdot 2$ & TR & $4 \cdot 8$ & $7 \cdot 1$ & $16 \cdot 9$ & - & $1 \cdot 1$ & $24 \cdot 0$ & $6 \cdot 2$ & $1 \cdot 6$ & & $1 \cdot 3$ & TR \\
\hline \multicolumn{14}{|c|}{ Ungrouped strains } \\
\hline 17 & $8 \cdot 1$ & $1 \cdot 3$ & 1.4 & - & - & - & TR & $18 \cdot 6$ & - & $40 \cdot 5$ & & - & TR \\
\hline 18 & - & $2 \cdot 3$ & - & - & - & - & - & 59.0 & - & $4 \cdot 2$ & & - & - \\
\hline
\end{tabular}

- , Not detected; TR, trace amount $(<1.0 \%)$. 
Table 4. Polar lipids as biomarkers in caulobacteria, Hyphomonas and Sphingomonas (found in strains listed in Table 1)

PC, Phosphatidylcholine; PG, phosphatidylglycerol; SQDG, 1,2-diacyl-3- $O$-sulfoquinovosylglycerol; TAU, 1,2-diacyl-3- $\alpha$-Dglucuronopyranosyl-sn-glycerol taurine amide; DGL, 1,2-di- $O$-acyl-3- $O$-[D-glucopyranosyl-(1 $\rightarrow 4)-\alpha$-Dglucopyranuronosyl]glycerol; PGL, 1,2-diacyl-3- $O$-[6'-phosphatidyl- $\alpha$-D-glucopyranosyl]glycerol; MGD, $1,2-$ di- $O$-acyl-3- $O$ - $\alpha$-Dglucopyranosyl glycerol; MGDOx, 1,2-di- $O$-acyl-3- $O$ - $\alpha$-D-glucopyranuronosyl glycerol. +++ , Present in all strains; ++ , present in most strains $(>80 \%)$; blank, absent.

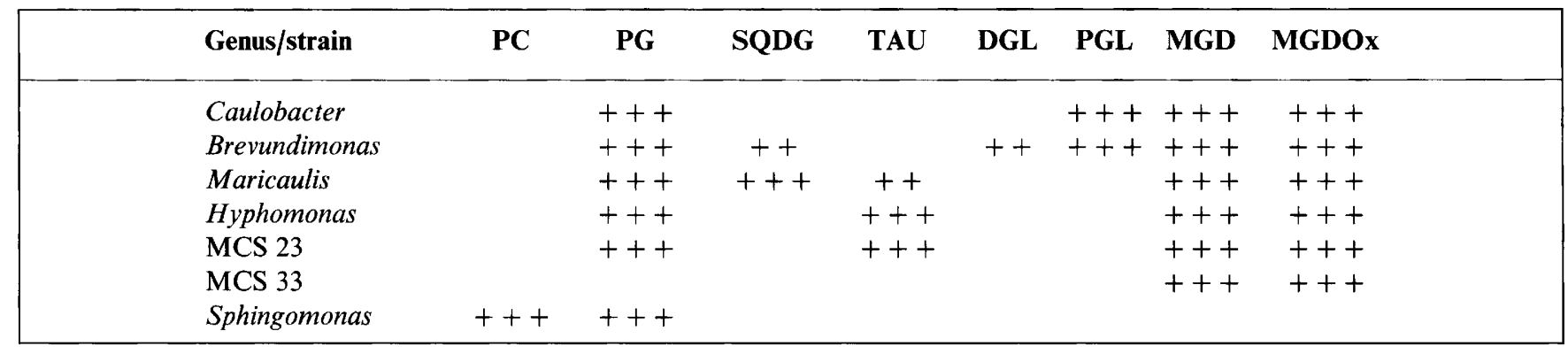

higher content of the dominant fatty acid sum7. The Maricaulis gen. nov. group was the only one where 11:0iso 3-OH, 17:0iso, 17:1iso $\omega 9 c$ and $18: 1 \omega 9 c$ were present and 12:0 3-OH and 12:1 3-OH were absent. Contrary to the other groups, 15:0 was found only in traces. The fourth group comprised Hyphomonas strains with considerable amounts of $17: 0$ and an unidentified fatty acid at ECL 18.797. C. leidyia differed from all these strains by the presence of large amount of 14:0 2-OH. Caulobacter sp. FWC 38 could also not be grouped mainly because of the huge amounts of trans-11-methyl-12-octadecenoic acid (ECL 18.080) found whereas sum7 (see Table 3) was considerably reduced.

\section{Mass spectrometric analysis of polar lipids (glyco- and phospholipids)}

The polar lipids were analysed by chromatographic and spectroscopic methods. ${ }^{1} \mathrm{H}-\mathrm{NMR}$ spectra of the polar lipid fractions of almost all strains revealed the presence of poly- $\beta$-hydroxybutyric acid. Individual polar lipids were analysed and their structures elucidated using tandem mass spectrometry (Abraham et al., 1997). From the strains included in this study, 26 different phosphoglucolipids could be identified. Although more than 30 different fatty acids were detected in the phospholipid fractions of Caulobacter, Brevundimonas and Mycoplana spp., only seven different fatty acids occurred within these 26 different phosphoglucolipids. Furthermore, three different sulfoquinovosyl diacylglycerols were detected. This lipid type occurred in all halophilic Caulobacter strains, in most Brevundimonas strains but only in few freshwater Caulobacter strains, while all Hyphomonas strains lacked these sulfolipids (Batrakov et al., 1996; Abraham et al., 1997). Glucuronotaurine amides were found only in the halophilic Caulobacter and Hyphomonas strains but were absent from the freshwater strains of Caulobacter and Brevundimonas and the halophilic bacterium MCS 33. The distribution of the different types of phospholipids, especially the sulfoquinovosyl diacylglycerols, glucuronotaurine amide diacylglycerols and phosphatidyl glucopyranosyl diacylglycerols, led to the identification of four different phenotypic groups of these bacteria, in agreement with the phylogenetic groupings published previously (Stahl et al., 1992) and the groupings derived from 16S rRNA gene sequences in this study. One group comprised Caulobacter sensu stricto with $C$. vibrioides. The second group comprised the type strains of Brevundimonas, including the type species $B$. diminuta and a considerable number of described Caulobacter spp. The third group included the halophilic Caulobacter spp. around C. maris. The latter group lacked the phosphatidyl glucopyranosyl diacylglycerols (present both in Caulobacter sensu stricto and Brevundimonas strains) but contained sulfoquinovosyl and glucuronotaurine amide diacylglycerols. They could be discerned from the fourth group, Hyphomonas, by the occurrence of sulfoquinovosyl diacylglycerols which were absent in strains of the genus Hyphomonas.

One characteristic of the genera analysed in this study was the high percentage of glycolipids within the polar lipids. Most strains contained higher amounts of glycothan phospholipids and some of them completely lacked phospholipids (Minnikin et al., 1973). The glycolipids were $\alpha$-D-glucopyranosyl diacylglycerol, $\alpha$ D-glucopyranuronosyl diacylglycerol and $\alpha$-Dglucopyranosyl-( $\rightarrow 4)$ - $\alpha$-D-glucopyranuronosyl diacylglycerol (Wilkinson, 1969; Batrakov et al., 1997). The mass spectrometric analysis of the glycolipids of 70 strains of Caulobacter, Mycoplana, Hyphomonas and Brevundimonas spp. has led to the identification of 60 different derivatives. A pattern of distribution of these glycolipids within the caulobacteria could be observed, where the glycolipids with a mass of 742 were more abundant in the halophilic caulobacteria than in any other group, Hyphomonas spp. contained more glucuronosyl lipids than the other groups and the occurrence of glucosyl glucuronosyl lipids was restricted to Brevundimonas spp. and closely 


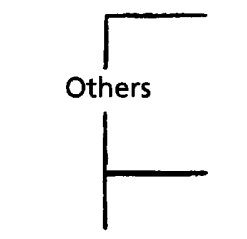

Brevundimonas

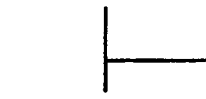

Maricaulis

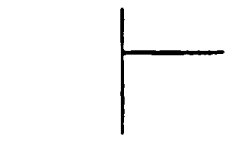

Brevundimonas

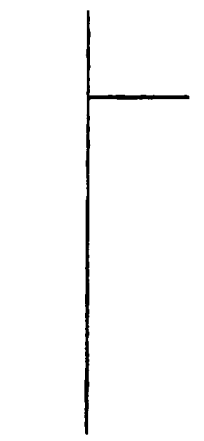

Caulobacter
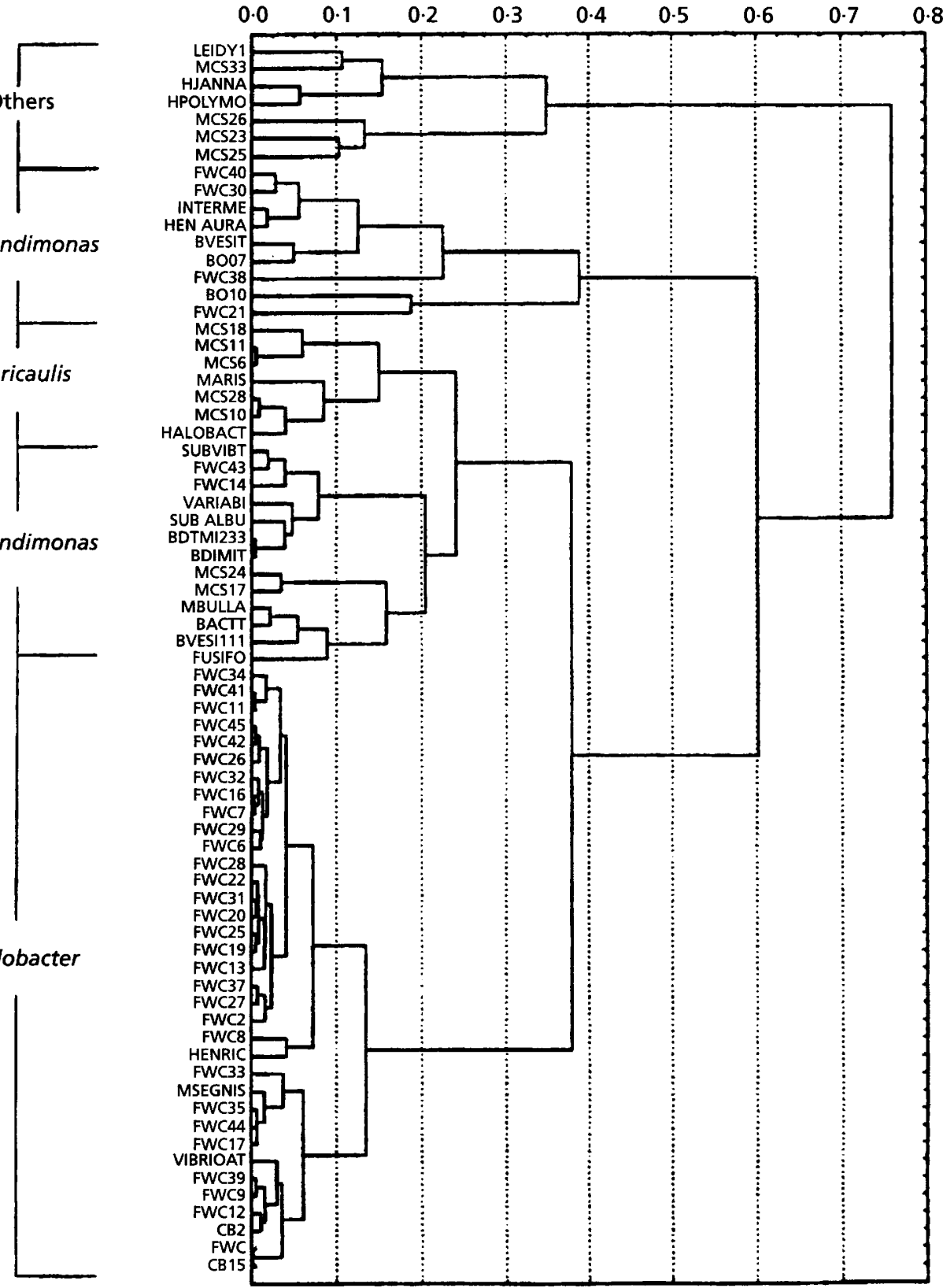

Fig. 7. Dendrogram derived from the relative intensities of the $\left[M+\mathrm{NH}_{4}\right]^{+}$ions between $\mathrm{m} / \mathrm{z} 740-840$ (most abundant ion set to $100 \%)$. Unweighted pair group means and Pearson's coefficient were used to construct the dendrogram.

related strains (Table 4). DCI mass spectrometry using ammonia as ionization gas showed mainly the $\left[M+\mathrm{NH}_{4}\right]^{+}$ions and was used to compare the strains. The relative intensities of the $\left[M+\mathrm{NH}_{4}\right]^{+}$ions between $m / z \quad 740-840$ were determined and compared by multivariate analysis. The dendrogram derived from these data revealed four groups of bacteria comprising Caulobacter sensu stricto, Brevundimonas, Maricaulis gen. nov. and a cluster containing Hyphomonas and other marine bacteria (Fig. 7).

\section{Westprinting analysis of Caulobacter and Brevundimonas strains}

To support the results of the 16S rDNA sequence and lipid analyses, an immunological approach has been taken for the identification of genus-specific antigens (Tesar et al., 1996) among the Caulobacter sensu stricto, Brevundimonas and Maricaulis gen. nov. strains. For that purpose, a representative strain of each group was used to elicit antibodies in rabbits 

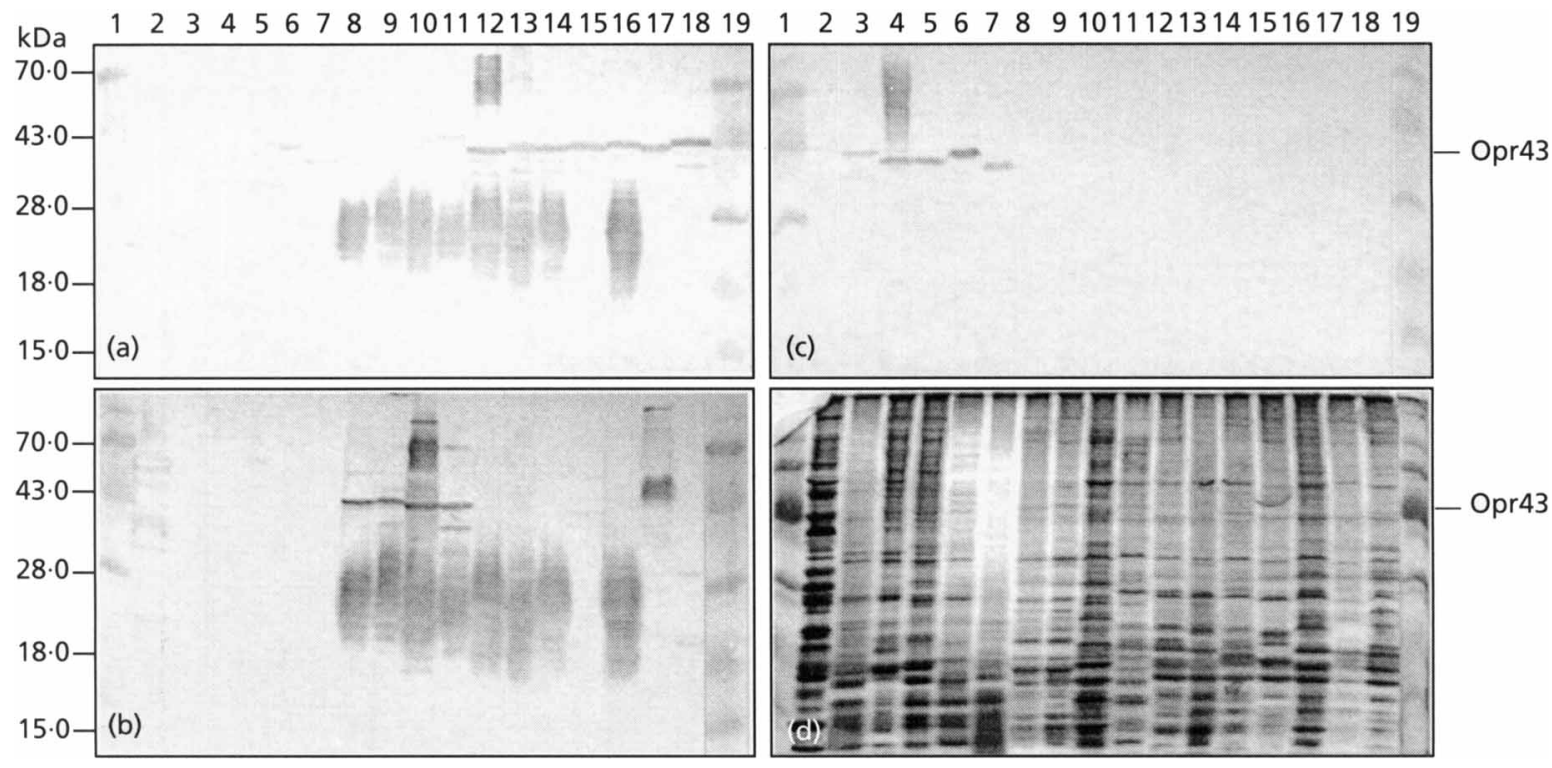

Fig. 8. Immunochemical analysis of different Caulobacter and Brevundimonas strains. Whole-cell lysates were subjected to SDS-PAGE followed by silver staining (d) or transfer to nitrocellulose membranes $(a, b, c)$. Immunoblots were incubated with antisera SMT7 (a), SMT7 (b) and SMT25 (c). Bound antibodies were detected by a peroxidase-coupled anti-rabbit antiserum. Bacterial strains and collection reference numbers for each lane are as follows: 2, C. leidyia ATCC 15260 ; 3, Caulobacter sp. MCS 28; 4, C. halobacteroides ATCC 15269 ; 5, Caulobacter sp. MCS 25; 6, Caulobacter sp. MCS 26; 7 , Caulobacter sp. MCS 18; 8, C. vibrioides ATCC 11764; 9, C. crescentus CB2 ${ }^{\top}$; 10, C. henricii ATCC 15253'; 11, C. fusiformis ATCC $15257^{\top} ; 12, B$. vesicularis LMG $2350^{\top} ; 13$, C. intermedius ATCC $15262^{\top} ; 14$, C. subvibrioides LMG $14903^{\top} ; 15$, Mycoplana bullata DSM 7126 $; 16$, C. alba DSM 4736 ${ }^{\top} ; 17$, C. bacteroides LMG $15096^{\top} ; 18$, B. diminuta LMG $2089^{\top} ; 1$ and 19: Molecular masses (in kDa) of standards.

which could be used for group-specific immunological fingerprints in a Western blot. Three different antisera raised against $C$. henricii (serum SMT7), B. vesicularis (serum SMT2) and Caulobacter maris (serum SMT25) reacted exclusively with a subset of Caulobacter and Brevundimonas strains (Table 1). Using the reactivity against a band of $43 \mathrm{kDa}$ in size as a group-specific biomarker (Fig. 8), the bacteria were clustered into three major groups. The first group of immunologically related strains, which reacted only with the serum SMT7, comprised freshwater isolates including the type strains of $C$. vibrioides, $C$. crescentus, $C$. henricii and $C$. fusiformis (Table 1). The second group of bacteria, which reacted exclusively with serum SMT2, showed a broader spectrum of strains isolated from different environments, including type strains $B$. vesicularis and $B$. diminuta as well as $C$. intermedius, $C$. subvibrioides, C. bacteroides, Mycoplana bullata and several freshwater and marine isolates (Table 1). A third group of Caulobacter strains which reacted exclusively with serum SMT25 included the type strains $C$. maris, $C$. halobacteroides and several other marine isolates (Table 1). These three groups fit with the genera Caulobacter sensu stricto, Brevundimonas and Maricaulis gen. nov. However, some strains described as Caulobacter isolates (MacRae \& Smit, 1991; Walker et al., 1992) showed only a weak reaction with the antisera, as in the case of Caulobacter sp. FWC 5, FWC 21 and FWC 38, or no reaction, as in the case of $C$. leidyia. Further analysis of the $43 \mathrm{kDa}$ biomarker showed that it was highly enriched in outermembrane protein fractions (data not shown).

\section{DISCUSSION}

Sequence comparisons of the PCR-amplified 16S rRNA genes, lipid analyses and salt tolerances enabled us to group Caulobacter spp. sensu lato and some related species into three different clusters corresponding to taxonomic genus levels. One group comprised Caulobacter sensu stricto, including the type species $C$. vibrioides (i.e. the described type species of the genus), $C$. henricii, C. fusiformis and Mycoplana segnis. This genus was characterized by the absence of diglycosyl and sulfoquinovosyl lipids, the presence of phosphatidyl glucosyl lipids with the main mass at $1411 \mathrm{Da}$ and minimal salt tolerances. The second genus comprised Brevundimonas spp., including the type species of $B$. diminuta and $B$. vesicularis as well as $C$. bacteroides, $C$. henricii subsp. aurantiacus, $C$. intermedius, $C$. subvibrioides, $C$. subvibrioides subsp. albus, C. variabilis and Mycoplana bullata. This group was characterized by the presence of diglycosyl, sulfoquinovosyl and phosphatidyl glucosyl lipids with main masses of 1413 and $1439 \mathrm{Da}$. These species tolerate salt at concentrations between $0-30 \mathrm{~g} \mathrm{NaCl}^{-1}$ (some species can grow in up to $60 \mathrm{~g} \mathrm{NaCl}^{-1}$ ). A third group comprised the genus Maricaulis gen. nov. and included 
C. maris and C. halobacteroides. This newly recognized genus was characterized by the presence of sulfoquinovosyl and glucuronopyranosyl taurine amide lipids, the absence of phosphoglucosyl lipid and salt tolerances between 10-60 g NaCl $1^{-1}$ (some species can grow in up to $80 \mathrm{~g} \mathrm{NaCl} \mathrm{l}^{-1}$ ). The occurrence of sulfoquinovosyl lipids in Maricaulis gen. nov. differentiated it from Hyphomonas, the species of which did not contain these lipids.

The genus Mycoplana is also paraphyletic, as shown by Yanagi \& Yamasato (1993). According to their analysis of the 16S rDNA sequence of Mycoplana dimorpha IAM $13154^{\mathrm{T}}$, the type strain of the type species belonged to the family Rhizobiaceae while Mycoplana bullata grouped near $B$. diminuta. We propose to remove Mycoplana segnis and Mycoplana bullata from the genus Mycoplana, which is classified within the Rhizobiaceae, and to place these two species into the genera Caulobacter and Brevundimonas, respectively. Further investigations are needed to clarify the taxonomic position of Mycoplana bullata within the genus Brevundimonas.

C. crescentus could not be discerned clearly from $C$. vibrioides by the various methods described above. The genetic criterion, accepted internationally, for discerning different species is a DNA-DNA homology below $70 \%$. Twenty years ago, Moore et al. (1978) reported the DNA-DNA homology between the neotype strain $C$. vibrioides $\mathrm{CB} 51^{\mathrm{T}}$ and $C$. crescentus $\mathrm{CB} 2^{\mathrm{T}}$ to be $97 \%$, but they did not formally propose $C$. crescentus to be synonymous with $C$. vibrioides. Our results, especially the analysis of the $16 \mathrm{~S}-23 \mathrm{~S}$ ISR rDNA, further revealed that strains FWC 16 and FWC 45 were indistinguishable from $C$. vibrioides DSM $9893^{\mathrm{T}}$ and $C$. crescentus $\mathrm{CB} 2^{\mathrm{T}}$, whereas both $C$. vibrioides ATCC 11764 and Caulobacter sp. FWC 26 showed differences in their interspacer regions. Moore et al. (1978) performed DNA-DNA hybridizations between all described Caulobacter species including three subspecies. Apart from $C$. vibrioides, $C$. crescentus and C. vibrioides subsp. limonus, they found, for all type strains, DNA-DNA homologies well below $70 \%$, identifying all of them as distinct species. Our results also proved that $C$. maris is conspecific with $C$. halobacteroides and a DNA-DNA homology of $92 \%$ further confirmed these results.

The analysis of the 16S rRNA genes of $C$. vibrioides DSM $9893^{\mathrm{T}}$ and VKM B-1496 ${ }^{\mathrm{T}}$ showed that both sequences were identical. On the basis of this work, it could be concluded that strains of $\mathrm{CB} 51^{\mathrm{T}}$, held in the DSMZ and in the VKM and obtained from two independent sources, were identical at the level of $16 \mathrm{~S}$ rDNA. Thus, it has been possible to show that the type strain of Caulobacter vibrioides, which the 'Approved Lists of Bacterial Names' (Skerman et al., 1989) lists as being 'not extant', and which was the type species of the genus Caulobacter, is in fact held in the DSMZ and VKM. It is now possible to properly define the genera Caulobacter and Brevundimonas, for which $C$. vibrioides and $B$. diminuta, respectively, are the type species.

All methods of this study demonstrated that $C$. leidyia could not be a member of any of the taxa described above, but rather belongs to the genus Sphingomonas, although further studies concerning the genus Sphingomonas are required before a recombination of C. leidyia as a species of Sphingomonas can be made. We found the $16 \mathrm{~S}$ rDNA sequences of $C$. leidyia strains ATCC $15260^{\mathrm{T}}$ and DSM $4733^{\mathrm{T}}$ to be identical to that of a strain wrongly labelled as Caulobacter subvibrioides (GenBank accession no. M83797; Stahl et al., 1992). We also investigated the 16S rDNA sequence of the type strain of $C$. subvibrioides and found it to fit into the Brevundimonas cluster, as has also been reported by Sly (1997). Another confusion concerns the type strain of $C$. bacteroides, in that the 16S rDNA sequence determined by Stahl et al. (1992) was identical to the $16 \mathrm{~S}$ rDNA sequence we have determined for C. fusiformis ATCC $15257^{\mathrm{T}}$, while the type strain of $C$. bacteroides, LMG $15096^{\mathrm{T}}$, appears in fact to be a member of the genus Brevundimonas.

The diverging polar lipids of some Caulobacter strains need some further discussion. Caulobacter sp. FWC 38 and $C$. fusiformis displayed lipids which were not found in other strains of the genus Caulobacter sensu stricto. The pattern of phosphoglycolipids of Caulobacter sp. FWC 38 was different from that of all other strains of both Caulobacter and Brevundimonas. The phosphoglycolipid with 1410 or $1412 \mathrm{Da}$ is missing, but the phosphoglycolipid of $1438 \mathrm{Da}$, which is characteristic of the phospholipids determined for species of the genus Brevundimonas, was found. C. fusiformis had the phosphoglycolipid of $1412 \mathrm{Da}$ but was otherwise similar to FWC 38. Both of them, however, did not contain diglycosyl lipids, another characteristic biomarker of the genus Brevundimonas. These results characterized these two strains at the margin of the genus Caulobacter near Brevundimonas. Surprisingly, Caulobacter sp. FWC 21 which is, according to the 16S rDNA data, even more remote from the 'core region' of the genus Caulobacter possessed a lipid pattern completely in agreement with the majority of Caulobacter strains.

Caulobacter strains have been compared based on the reactivity of an antiserum raised against the $S$-layer protein of C. crescentus CB15 (rsaA gene) (Walker et al., 1992). However, the use of S-layer antisera is not especially suitable as a taxonomic aid since S-layers might be lost when grown under laboratory conditions (Koval et al., 1991), and thus escape identification by immunological probes against S-layer proteins. Moreover, some freshwater strains and all marine strains lack an S-layer (Walker et al., 1992; Anast \& Smit 1988). Recently, a new strategy, termed 'Westprinting' (Western blot and immunological fingerprinting) has been described (Tesar et al., 1996) which allows a systematic screening of genus- and strain-specific protein epitopes based on similar or identical protein 
patterns among different strains of a taxon of interest. In this study, we used the Westprinting technique to identify antigenic epitopes among immuno-reactive proteins, which could serve as group-specific biomarkers for the identification of caulobacteria. Based on the reactivity of several antisera, a $43 \mathrm{kDa}$ protein was identified as a protein biomarker which exhibited group-specific epitopes useful for the clustering of strains of Caulobacter and Brevundimonas into three different sub-groups, which was in good agreement with the $16 \mathrm{~S}$ rDNA sequence and polar lipid analyses. Further studies revealed that the $43 \mathrm{kDa}$ protein was highly enriched in the outer-membrane protein fraction. This contributes to the findings of others, that outer-membrane proteins share common immunogenic epitopes within a phylogenetically related group of bacteria (Hancock et al., 1990; Ullstrom et al., 1991; Kragelund et al., 1996). However, the identity of the $43 \mathrm{kDa}$ protein remains to be solved and further studies are in progress to analyse the $\mathrm{N}$ terminal sequence for comparison with other outermembrane proteins.

The results of this study demonstrated that cell morphology did not necessarily correlate with the phylogenetic relationships of bacteria. However, this general observation has been reported previously (e.g. Vandamme et al., 1996). Our findings have revealed the important observation, that the morphologically characteristic 'prostheca' is paraphyletic. We could not see any prostheca in $B$. diminuta LMG $2089^{\mathrm{T}}$ and Mycoplana bullata DSM $7126^{\mathrm{T}}$ cells grown under conditions where all Caulobacter strains developed them. To date, only the newly proposed genus Maricaulis comprised entirely strains with prosthecae while Brevundimonas and Caulobacter sensu stricto contain both types. The presence of the prostheca-less species Mycoplana segnis in the genus Caulobacter, the membership of the prosthecate $C$. bacteroides or $C$. intermedius in the hitherto prostheca-less genus Brevundimonas or the prosthecate $C$. leidyia in the genus Sphingomonas demonstrate that either this morphology has developed several times during the evolution of the $\alpha$-Proteobacteria and/or it was lost repeatedly. The observation that an isolate identified as $B$. vesicularis hybridized with a flagellin gene probe (Stahl et al., 1992) suggests, at least in the case of the closely related Brevundimonas species, the possibility that these strains are locked in the motile phase.

\section{Conclusions}

Due to the heterogeneity of the genera Caulobacter and Mycoplana, certain recombinations are required and the proposal of the new genus Maricaulis for halophilic Caulobacter strains is necessary.

\section{Caulobacter Henrici and Johnson 1935 emend.}

The description of the genus Caulobacter given by Henrici \& Johnson (1935) and emended by Poindexter (1964) must be further emended.
Gram-negative cells, rod-shaped, fusiform or vibroid, $0 \cdot 4-0.5$ by $1-2 \mu \mathrm{m}$. Cells usually possess a prostheca, but some species do not. They tolerate only small amounts of $\mathrm{NaCl}$, grow without it, but some grow optimally with $5 \mathrm{~g} \mathrm{NaCl} 1^{-1}$. No growth with salt concentrations above $20 \mathrm{~g} \mathrm{l}^{-1}$ was observed. All strains contain significant amounts of the fatty acids $12: 13$ $\mathrm{OH}, 14: 0,16: 0$, sum4 (see Table 3), sum7 (see Table 3) and 11-Me 18:1 155 (ECL 18.080). All strains, except Mycoplana segnis, additionally contain ECL 11.798 , $15: 0,17: 0,17: 1 \omega 6 c$ and $17: 1 \omega 8 c$. Polar lipids are $\alpha$-D-glucopyranosyl diacylglycerol, $\alpha$-D-glucopyranuronosyl diacylglycerol, 6-phosphatidyl- $\alpha$-D-glucopyranosyl diacylglycerol (main mass number $1411 \mathrm{Da}$ ) and phosphatidylglycerol. The $\mathrm{G}+\mathrm{C}$ content is $62-67 \mathrm{~mol} \%$. Type species is Caulobacter vibrioides.

Caulobacter vibrioides Henrici and Johnson 1935 (syn. Caulobacter crescentus Poindexter 1964) (Moore et al., 1978). Neotype strain is CB51 ${ }^{\mathrm{T}}$ (=VKM B-1496 ${ }^{\mathrm{T}}$ ). Conspecific are strains $\mathrm{CB} 2^{\mathrm{T}}, \mathrm{CB} 15$ and $\mathrm{CB} 16$ (Moore et al., 1978).

Caulobacter segnis comb. nov. Basonym: Mycoplana segnis Urakami et al. 1990. Caulobacter segnis is closely related to $C$. vibrioides according to $16 \mathrm{~S}$ rRNA gene sequence similarity, but is clearly distinct from this species by morphology and cell cycle (Urakami et al., 1990). Differs from C. vibrioides by the presence of ECL 18.140 and the lack of ECL 11.798, 15:0, 17:0, $17: 1 \omega 6 c$ and $17: 1 \omega 8 c$ in the whole-cell hydrolysate. Type strain is DSM $7131^{\mathrm{T}}$ (= LMG $\left.17158^{\mathrm{T}}\right)$.

\section{Brevundimonas Segers et al. 1994 emend.}

Gram-negative cells, rod-shaped, fusiform, bacteroid or vibroid, $0.4-0.5$ by $1-2 \mu \mathrm{m}$. Cells do not usually possess a prostheca, but some species do. They grow without $\mathrm{NaCl}$, grow optimally with $5-20 \mathrm{~g} \mathrm{NaCl}^{-1}$, growth is reduced at $30-80 \mathrm{~g} \mathrm{NaCl}^{-1}$ depending on the species, and they do not grow with $\mathrm{NaCl}$ concentrations above $80 \mathrm{~g}^{-1}$. Dominant fatty acids for all Brevundimonas strains are 12:0 3-OH, 14:0, 15:0, 16:0, sum4, 17:0, 17:1 $\omega 6 c, 17: 1 \omega 8 c$ and sum7. They are differentiated from Caulobacter strains by the absence of ECL 11.789 and significant amounts of $12: 13-\mathrm{OH}$, by the presence of at least traces of ECL 17.897 and higher amounts of $12: 03-\mathrm{OH}$, and by a higher content of the dominant fatty acid sum7 (see Table 3). Polar lipids are $\alpha$-D-glucopyranosyl diacylglycerol, $\alpha$-D-glucopyranuronosyl diacylglycerol, 1,2-di- $O$-acyl-3- $O$-[D-glucopyranosyl- $(1 \rightarrow 4)-\alpha$-Dglucopyranuronosyl]glycerol, 6-phosphatidyl- $\alpha-D-$ glucopyranosyl diacylglycerol (main mass numbers 1413 and $1439 \mathrm{Da}$ ), and phosphatidylglycerol. Most strains contain sulfoquinovosyl diacylglycerol. The $\mathrm{G}+\mathrm{C}$ content is $65-68 \mathrm{~mol} \%$. Type species is Brevundimonas diminuta; type strain is LMG $2089^{\mathrm{T}}$.

Brevundimonas alba comb. nov., stat. nov. Basonym: Caulobacter subvibrioides subsp. albus Poindexter 1964. Closest relative is Brevundimonas intermedia to 
which it is $98.1 \%$ related by $16 \mathrm{~S}$ rDNA similarity and $15 \%$ by DNA-DNA homology (Moore et al., 1978). Type strain is DSM $4736^{\mathrm{T}}\left(=\mathrm{CB} 88^{\mathrm{T}}\right)$.

Brevundimonas aurantiaca comb. nov., stat. nov. Basonym: Caulobacter henricii subsp. aurantiacus Poindexter 1964. Closest relative is $B$. intermedia to which it is $99 \cdot 2 \%$ related by $16 \mathrm{~S}$ rDNA similarity and $33 \%$ by DNA-DNA homology (Moore et al., 1978). Type strain is DSM $4731^{\mathrm{T}}\left(=\mathrm{CB}-\mathrm{R}^{\mathrm{T}}\right)$.

Brevundimonas bacteroides comb. nov. Basonym: Caulobacter bacteroides Poindexter 1964. Closest relative is B. variabilis to which it is $97.9 \%$ related by $16 \mathrm{~S}$ rDNA similarity and $13 \%$ by DNA-DNA homology (Moore et al., 1978). Type strain is ATCC $15254^{\mathrm{T}}(=$ $\mathrm{CB} 7^{\mathrm{T}}=\mathrm{LMG} 15096^{\mathrm{T}}$ ).

Brevundimonas intermedia comb. nov. Basonym: Caulobacter intermedius Poindexter 1964. Closest relative is B. vesicularis to which it is $99.9 \%$ related by $16 \mathrm{~S} \mathrm{rDNA}$ similarity, but differs by morphology and cell cycle. Another close relative is $B$. aurantiaca to which it is $99 \cdot 2 \%$ related by $16 \mathrm{~S}$ rDNA similarity and $33 \%$ by DNA-DNA homology (Moore et al., 1978). Type strain is ATCC $15262^{\mathrm{T}}\left(=\mathrm{CB} 63^{\mathrm{T}}\right)$.

Brevundimonas subvibrioides comb. nov. Basonym: Caulobacter subvibrioides Poindexter 1964. Closest relative is Mycoplana bullata to which it is $98.3 \%$ related by $16 \mathrm{~S}$ rDNA similarity, but is clearly distinct from this species by morphology and cell cycle (Urakami et al., 1990). Type strain is ATCC $15264^{\mathrm{T}}$ $\left(=\mathrm{CB} 81^{\mathrm{T}}=\mathrm{LMG} 14903^{\mathrm{T}}\right)$.

Brevundimonas variabilis comb. nov. Basonym: Caulobacter variabilis Poindexter 1989. Closest relative is $B$. alba to which it is $98.1 \%$ related by $16 \mathrm{~S}$ rDNA similarity and $1 \%$ by DNA-DNA homology (Moore et al., 1978). Type strain is ATCC $15255^{\mathrm{T}}\left(=\mathrm{CB} 17^{\mathrm{T}}\right)$.

\section{Description of Maricaulis gen. nov.}

Maricaulis (Ma.ri.cau'lis. L. neut. n. mare the sea; L. masc. n. caulis stalk referring to a prostheca; M.L. masc. n. Maricaulis stalk from the sea).

Gram-negative cells, rod-shaped, fusiform or vibroid, $0.4-0.5$ by $1-2 \mu \mathrm{m}$. Cells possess a prostheca, ca. $0.15 \mu \mathrm{m}$ in diameter and of varying length depending on the species and environmental conditions, extending from one pole as a continuation of the long axis of the cell. Adhesive material is present at the distal end of the prostheca. Occur singly. Multiplication by binary fission. At the time of separation one cell possesses a prostheca and the other a single polar flagellum. Each new appendage occurs at the cell pole opposite to the one formed during fission. The flagellated cell secretes adhesive material at the base of the flagellum, develops a prostheca at this site and enters the immotile vegetative phase. Colonies circular, convex, colourless. Chemo-organotrophic aerobes, but most of the strains tested could grow anaerobically probably using amino acid as fermentable carbon source (Anast \& Smit, 1988). Nitrate is reduced to nitrite anaerobically by some strains. Most strains can store carbon as poly- $\beta$-hydroxybutyric acid. As well as mixtures of B vitamins and amino acids, other organic factors are required for growth. All strains can grow on peptone yeast extract media with $5 \mathrm{~g} \mathrm{NaCl}^{-1}$; optimal growth between $20-60 \mathrm{~g} \mathrm{NaCl} 1^{-1}$. NaCl is required for optimal growth, only a few strains tolerate salt concentrations above $100 \mathrm{~g} \mathrm{NaCl}^{-1}$. Growth is inhibited or cells become deformed in media containing $1 \%(\mathrm{w} / \mathrm{v})$ or more organic material. Temperature range of most isolates is $15-35^{\circ} \mathrm{C} ; 20-25^{\circ} \mathrm{C}$ is optimal. The optimal $\mathrm{pH}$ for growth is around neutrality, $\mathrm{pH}$ range is $6 \cdot 0-8 \cdot 0$. All strains are characterized by three major fatty acids 16:0, 17:1iso $\omega 9 c$ and sum7 (see Table 3) and the following minor compounds: 11:0iso 3-OH, 17:1 $\omega 8,17: 0$ iso, 17:0,

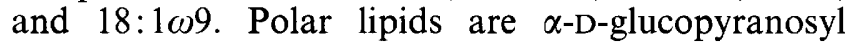
diacylglycerol, $\alpha$-D-glucopyranuronosyl diacylglycerol, sulfoquinovosyl diacylglycerol, $\alpha$-D-glucuronopyranosyl diacylglycerol taurine amide. Most strains contain also phosphatidylglycerol. All isolates were obtained only from sea water. The $\mathrm{G}+\mathrm{C}$ content is $62.5-64.0 \mathrm{~mol} \%$. The type species is Maricaulis maris.

Maricaulis maris comb. nov. Basonym: Caulobacter maris Poindexter 1964. Type strain is ATCC $15268^{\mathrm{T}}$ (= CM $\left.11^{\mathrm{T}}\right)$. The $\mathrm{G}+\mathrm{C}$ content is $62.5 \mathrm{~mol} \%$. Synonym: Caulobacter halobacteroides Poindexter 1964 ATCC $15269^{\mathrm{T}}\left(=\mathrm{CM} 13^{\mathrm{T}}\right)(\mathrm{DNA}-\mathrm{DNA}$ homology between the two type strains is $92 \%$ ).

\section{ACKNOWLEDGEMENTS}

We thank Dagmar Duttmann, Andrea Brinkop, Tanja Jeschke, Birgit Jung, Annette Krüger and Peter Wolff for their excellent technical assistance. Ingo Fritz kindly provided two marine Brevundimonas $\mathrm{sp}$. isolated from the Mediterranean. This work was supported by grants from the German Federal Ministry for Science, Education and Research (Projects No. 0319433B and 0319433C) and the European Union within the T-project 'High Resolution Automated Microbial Identification and Application to Biotechnologically Relevant Ecosystems'. A.B. acknowledges the support by grants BIO91-0659 and MAR91-0341 from the Comisión Interministerial de Ciencia y Tecnología (CICYT) and J.S. thanks the Natural Sciences and Engineering Research Council of Canada for support. B. J.T. would like to thank Professor J. T. Staley, University of Washington, Seattle, USA and Dr. M. Vainhstein, Puschino, Russia for kindly providing Caulobacter vibrioides $\mathrm{CB}^{\mathrm{T}} 1^{\mathrm{T}}\left(=\mathrm{DSM} 9893^{\mathrm{T}}\right)$ and VKM B-1496 ${ }^{\mathrm{T}}\left(=\mathrm{CB} 51^{\mathrm{T}}\right)$.

\section{REFERENCES}

Abraham, W.-R., Meyer, H., Lindholst, S., Vancanneyt, M. \& Smit, J. (1997). Phospho- and sulfolipids as biomarkers of Caulobacter, Brevundimonas and Hyphomonas. Syst Appl Microbiol 20, 522-539.

Anast, N. \& Smit, J. (1988). Isolation and characterization of marine caulobacters and assessment of their potential for generic experimentation. Appl Environ Microbiol 54, 809-817. 
Andreev, L. V., Akimov, V. N. \& Nikitin, D. I. (1986). Peculiarities of fatty acid composition of the genus Caulobacter. Folia Microbiol 31, 144-153.

Batrakov, S. G., Nikitin, D. I. \& Pitryuk, I. A. (1996). A novel glycolipid, 1,2-diacyl-3- $\alpha$-D-glucuronopyranosyl-sn-glycerol taurine amide, from the budding seawater bacterium Hyphomonas jannaschiana. Biochim Biophys Acta 1302, 167-176.

Batrakov, S. G., Nikitin, D. I., Sheichenko, V. I. \& Ruzhitsky, A. O. (1997). Unusual lipid composition of the gram-negative, freshwater, stalked bacterium Caulobacter bacteroides NP-105. Biochim Biophys Acta 1347, 127-139.

Bligh, E. G. \& Dyer, W. J. (1959). A rapid method for total lipid extraction and purification. Can J Biochem Physiol 37, 911-917.

Brosius, J., Palmer, M. L., Kennedy, P. J. \& Noller, H. F. (1978). Complete nucleotide sequence of a $16 \mathrm{~S}$ ribosomal RNA gene from Escherichia coli. Proc Natl Acad Sci USA 75, 4801-4105.

Brosius, J., Dull, T. J. \& Noller, H. F. (1980). Complete nucleotide sequence of a $23 \mathrm{~S}$ ribosomal RNA gene from Escherichia coli. Proc Natl Acad Sci USA 77, 201-204.

Carter, R. N. \& Schmidt, J. M. (1976). Fatty acid composition of selected prosthecate bacteria. Arch Microbiol 110, 91-94.

De Ley, J., Cattoir, H. \& Reynaerts, A. (1970). The quantitative measurement of DNA hybridization from renaturation rates. Eur J Biochem 12, 133-142.

Edwards, U., Rogall, T., Bloecker, H., Emde, M. \& Boettger, E. (1989). Isolation and direct complete nucleotide determination of entire genes. Characterization of a gene coding for $16 \mathrm{~S}$ ribosomal RNA. Nucleic Acids Res 17, 7843-7853.

Felsenstein, J. (1989). PHYLIP - phylogeny inference package (version 3.2). Cladistics 5, 164-166.

Filip, C., Fletcher, G., Wulff, J. L. \& Earhardt, C. F. (1973). Solubilization of the cytoplasmic membrane of Escherichia coli by the ionic detergent sodium-lauryl sarcosinate. $J$ Bacteriol 115, 717-722.

Gutell, R. R., Weiser, B., Woese, C. R. \& Noller, H. F. (1985). Comparative anatomy of 16S-like ribosomal RNA. Prog Nucleic Acid Res Mol Biol 32, 155-216.

Hancock, R. E. W. \& Carey, A. M. (1979). Outer membrane of $P$. aeruginosa: heat- and 2-mercaptoethanol-modifiable proteins. $J$ Bacteriol 140, 902-910.

Hancock, R. E. W., Siehnel, R. \& Martin, N. (1990). Outer membrane proteins of Pseudomonas. Mol Microbiol 4, 1069-1075.

Harlow, D. \& Lane, D. (1988). Antibodies: a Laboratory Manual. Cold Spring Harbor, NY: Cold Spring Harbor Laboratory.

Henrici, A. T. \& Johnson, D. E. (1935). Studies on fresh water bacteria. II. Stalked bacteria, a new order of schizomycetes. $J$ Bacteriol 30, 61-93.

Jannasch, H. W. \& Jones, G. E. (1960). Caulobacter in sea water. Limnol Oceanogr 5, 432-433.

Judd, R. C. (1988). Purification of outer membrane proteins from the gram-negative bacterium Neisseria gonorrhoeae. Anal Biochem 173, 307-316.

Jukes, T. H. \& Cantor, C. R. (1969). Evolution of protein molecules. In Mammalian Protein Metabolism, vol. 3, pp. 21-132. Edited by H. N. Munro. New York: Academic Press.

Karlson, U., Dwyer, D. F., Hooper, S. W., Moore, E. R. B., Timmis, K. N. \& Eltis, L. D. (1993). Two independently regulated cytochromes P-450 in a Rhodococcus rhodochrous strain that degrades 2-ethoxyphenol and 4-methoxybenzoate. $J$ Bacteriol $175,1467-1474$.

Koval, S. F. \& Hynes, S. H. (1991). Effect of paracrystalline protein surface layers on predation by Bdellovibrio bacteriovorus. J Bacteriol 173, 2244-2249.

Kragelund, L., Leopold, K. \& Nybroe, O. (1996). Outer membrane heterogeneity within Pseudomonas fluorescens and P. putida and use of an oprF antibody as a probe for rRNA homology group I pseudomonads. Appl Environ Microbiol 62, 480-485.

Laemmli, U. K. (1970). Cleavage of structural proteins during the assembly of the head of bacteriophage T4. Nature 227, 680-685.

Lane, D. J. (1991). 16S $/ 23 \mathrm{~S}$ sequencing. In Nucleic Acid Techniques in Bacterial Systematics, pp. 115-175. Edited by E. Stackebrandt \& M. Goodfellow. Chichester: Wiley.

Lapteva, N. A. (1987). Ecological characteristics of Caulobacter incidence in fresh-water basins. Mikrobiologiya 56, 677-684.

Loeffler, F. (1890). Weitere Untersuchungen über die Beizung und Färbung der Geisseln bei den Bakterien. Centralbl Bakteriol Parasitenkd 7, 625-639.

MacRae, J. D. \& Smit, J. (1991). Characterization of caulobacters isolated from wastewater treatment systems. Appl Environ Microbiol 57, 751-758.

Maizel, J. V. (1969). Acrylamide gel electrophoresis of proteins and nucleic acids. In Functional Techniques in Virology, pp. 334-362. Edited by K. Habel \& N. P. Salzman. New York: Academic Press.

Marmur, J. (1961). A procedure for the isolation of deoxyribonucleic acid from micro-organisms. $J \mathrm{Mol} \mathrm{Biol} \mathrm{3,} \mathrm{208-218.}$

Medlin, L., Elwood, H. J., Stickel, S. \& Sogin, M. L. (1988). The characterization of enzymatically amplified eukaryotic 16S-like rRNA coding regions. Gene 71, 491-499.

Mesbah, M., Premachandran, U. \& Whitman, W. B. (1989). Precise measurement of the $\mathrm{G}+\mathrm{C}$ content of deoxyribonucleic acid by high-performance liquid chromatography. Int J Syst Bacteriol 39, 159-167.

Minnikin, D. E., Abdolrahimzadeh, H., Baddiley, J. \& Wilkinson, S. G. (1973). Glycolipids and biological membranes. Replacement of phospholipids by glycolipids in Pseudomonas diminuta. Biochem Soc Trans 1, 431-432.

Moore, R. L., Schmidt, J., Poindexter, J. \& Staley, J. T. (1978), Deoxyribonucleic acid homology among the caulobacters. Int $J$ Syst Bacteriol 28, 349-353.

Nikitin, D. L., Vishnewetskaya, O. Y., Chumakov, K. M. \& Zlatkin, I. V. (1990). Evolutionary relationship of some stalked and budding bacteria (genera Caulobacter, 'Hyphobacter', Hyphomonas and Hyphomicrobium) as studied by the new integral taxonomic method. Arch Microbiol 153, 123-128.

Orita, M., Suzuki, Y., Sekiya, T. \& Hayashi, K. (1989). Rapid and sensitive detection of point mutation and DNA polymorphisms using polymerase chain reaction. Genomics 5, 874-879.

Osterhout, G. J., Shull, V. H. \& Dick, J. D. (1991). Identification of clinical isolates of Gram-negative nonfermentative bacteria by an automated cellular fatty acid identification system. $J$ Clin Microbiol 29, 1822-1830.

Poindexter, J. S. (1964). Biological properties and classification of the Caulobacter group. Bacteriol Rev 28, 231-295.

Poindexter, J. S. (1981a). Oligotrophy. Fast and famine existence. In Microbial Ecology, vol. 5, pp. 63-89. Edited by M Alexander. New York: Plenum.

Poindexter, J. S. (1981b). The Caulobacters: ubiquitous unusual bacteria. Microbiol Rev 45, 123-179. 
Poindexter, J. S. (1989). Genus Caulobacter Henrici and Johnson 1935, 83 ${ }^{\mathrm{AL}}$. In Bergey's Manual of Systematic Bacteriology, vol. 3, pp. 1924-1939. Edited by J. T. Staley, M. P. Bryant, N. Pfennig \& J. G. Holt. Baltimore: Williams \& Wilkins.

Poindexter, J. S. \& Lewis, R. F. (1966). Recommendations for revision of the taxonomic treatment of stalked bacteria. Int $J$ Syst Bacteriol 16, 377-382.

Segers, P., Vancanneyt, M., Pot, B., Torck, U., Hoste, B., Dewettinck, D., Falsen, E., Kersters, K. \& De Vos, P. (1994). Classification of Pseudomonas diminuta Leifson and Hugh 1954 and Pseudomonas vesicularis Büsing, Döll and Freytag 1953 in Brevundimonas gen. nov. as Brevundimonas diminuta comb. nov. and Brevundimonas vesicularis comb. nov., respectively. Int $J$ Syst Bacteriol 44, 499-510.

Skerman, V. B. D., McGowan, V. \& Sneath, P. H. A. (1989). Approved Lists of Bacterial Names. Washington, DC: American Society for Microbiology.

Sly, L. I., Cahill, M. M., Majeed, K. \& Jones, G. (1997). Reassessment of the phylogenetic position of Caulobacter subvibrioides. Int J Syst Bacteriol 47, 211-213.

Stackebrandt, E., Fischer, A., Roggentin, T., Wehmeyer, U., Bomar, D. \& Smida, J. (1988). A phylogenetic survey of budding, and/or prosthecate, non-phototrophic eubacteria: membership of Hyphomicrobium, Hyphomonas, Pedomicrobium, Filomicrobium, Caulobacter and 'Dichotomicrobium' to the alphasubdivision of purple non-sulfur bacteria. Arch Microbiol 159, 547-556.

Stahl, D. A., Key, R., Flesher, B. \& Smit, J. (1992). The phylogeny of marine and freshwater caulobacters reflects their habitat. $J$ Bacteriol 174, 2193-2198.

Staley, J. T. (1968). Prosthecomicrobium and Acalomicrobium: new prosthecate freshwater bacteria. $J$ Bacteriol 95, 1921-1942.

Staley, J. T., Konopka, A. E. \& Dalmasso, J. P. (1987). Spatial and temporal distribution of Caulobacter spp. in two mesotrophic lakes. FEMS Microbiol Ecol 45, 1-6.

Tamaoka, J. \& Komagata, K. (1984). Determination of DNA base composition by reversed-phase high-performance liquid chromatography. FEMS Microbiol Lett 25, 125-128.

Tesar, M. \& Marquardt, O. (1990). Foot-and-mouth disease virus protease $3 \mathrm{C}$ inhibits cellular transcription and mediates cleavage of histone H3. Virology 174, 364-374.

Tesar, M., Hoch, C., Moore, E. R. B. \& Timmis, K. (1996). Westprinting: development of a rapid immunochemical identification for species within the genus Pseudomonas sensu stricto. Syst Appl Microbiol 19, 577-588.
Tindall, B. J. (1990a). A comparative study of the lipid composition of Halobacterium saccharovorum from various sources. Syst Appl Microbiol 13, 128-130.

Tindall, B. J. (1990b). Lipid composition of Halobacterium lacusprofundi. FEMS Microbiol Lett 66, 199-202.

Towbin, H., Staehelin, T. \& Gordon, J. (1979). Electrophoretic transfer of proteins from polyacrylamide gels to nitrocellulose sheets: procedures and some applications. Proc Natl Acad Sci USA 76, 4350-4354.

Ullstrom, C. A., Siehnel, R., Woodroff, W., Steinbach, S. \& Hancock, R. E. W. (1991). Conservation of the gene for outer membrane protein OprF in the family Pseudomonadaceae: sequence of the Pseudomonas syringae oprF gene. $J$ Bacteriol 173, 768-775.

Urakami, T., Oyanagi, H., Araki, H., Suzuku, K.-I. \& Komagata, K. (1990). Recharacterization and emended description of the genus Mycoplana and description of two new species, Mycoplana ramosa and Mycoplana segnis. Int J Syst Bacteriol 40, 434-442.

Vancanneyt, M., Witt, S., Abraham, W.-R., Kersters, K. \& Fredrickson, H. L. (1996). Fatty acid content in whole-cell hydrolysates and phospholipid fractions of pseudomonads: a taxonomic evaluation. Syst Appl Microbiol 19, 528-540.

Vandamme, P., Pot, B., Gillis, M., De Vos, P., Kersters, K. \& Swings, J. (1996). Polyphasic taxonomy, a consensus approach to bacterial systematics. Microbiol Rev 60, 407-438.

Walker, S. G., Smith, S. H. \& Smit, J. (1992). Isolation and comparison of the paracrystalline surface layer proteins of freshwater caulobacters. $J$ Bacteriol 174, 1783-1792.

Wilkinson, S. G. (1969). Lipids of Pseudomonas diminuta. Biochim Biophys Acta 187, 492-500.

Wilkinson, S. G. \& Bell, M. E. (1971). The phosphoglucolipid from Pseudomonas diminuta. Biochim Biophys Acta 248, 293-299.

Willems, A., Busse, J., Goor, M. \& 8 other authors (1989). Hydrogenophaga, a new genus of hydrogen-oxidizing bacteria that includes Hydrogenophaga flava comb. nov. (formerly Pseudomonas flava), Hydrogenophaga palleroni (formerly Pseudomonas palleroni), Hydrogenophaga pseudoflava (formerly Pseudomonas pseudoflava and 'Pseudomonas carboxydoflava'), and Hydrogenophaga taeniospiralis (formerly Pseudomonas taeniospiralis). Int J Syst Bacteriol 39, 319-333.

Yanagi, M. \& Yamasato, K. (1993). Phylogenetic analysis of the family Rhizobiaceae and related bacteria by sequencing of $16 \mathrm{~S}$ rRNA gene using PCR and DNA sequence. FEMS Microbiol Lett 107, 115-120. 